\title{
Bodemkwaliteitsbeoordeling van landbouwgronden in Nederland - Indicatorset en systematiek, versie 1.0
}

\section{Woord vooraf}

De minister van LNV is in 2019 gestart met het nationaal programma landbouwbodems (Ministerie van LNV, 2019). Het doel van dit programma is om publieke en private partijen te committeren aan het streefdoel: alle Nederlandse landbouwbodems duurzaam beheerd in 2030. Hiervoor wil de minister met Wageningen University \& Research (WUR) en samen met belanghebbenden een eenduidig

meetinstrumentarium ontwikkelen voor bodemkwaliteit. it rapport beschrijft de indicatorset "Bodemindicatoren voor Landbouwgronden in Nederland", BLN versie 1.0 en een eeste aanzet voor een robuuste systematiek. Daarbij bundelt het twee ontwikkelingen van WUR waarin gewerkt werd aan het opstellen van meetinstrumenten voor bodemkwaliteit: Binnen de voorganger van de PPS Beter Bodembeheer heeft WUR Open Teelten in de periode 2012-2015 gewerkt aan de Minimale Dataset Bodem (MDS). Een beperkte set van indicatoren die naar het oordeel van onderzoekers, getoetst met stakeholders het beste de bodemkwaliteit beschrijven. De parameters zijn vervolgens geordend in de mate van belang voor (karakterisering) de bodemkwaliteit. In het rapport worden de bodemparameters en de gekozen rangorde beschreven met (indien bekend) de meeteenheid, de streefwaarde (streeftraject), de mate van stuurbaarheid, de gewenste meetfrequentie (in de tijd en ruimte), de bemonsteringsmethodiek en de methodiek van analyse (de Haan et al. 2019).

Onderzoekers van Wageningen Environmental Research werkten aan een vertaling van het Amerikaanse CASH systeem (Comprehensive Assessment of Soil Health) naar de Nederlandse context, in opdracht van het KB-programma KBWOT. Op basis van internationale studies en een beschrijving van de hedendaagse bodembedreigingen in Nederland, is een set van indicatoren afgeleid die de bodemkwaliteit voor landbouwproductie beschrijft (van den Elsen et al., 2019).
Marjoleine Hanegraaf, Erik van den Elsen, Janjo de Haan \& Saskia Visser

Dit onderzoek is in opdracht van het Ministerie van LNV uitgevoerd door de Stichting Wageningen Research (WR), Wageningen University \& Research Open Teelten en Wageningen Environmental Research

Rapport WPR -795

Wageningen, juli 2019

Hanegraaf, M.C., H.G.M. van den Elsen, J.J. de Haan \& S.M. Visser (2019). Bbodemkwaliteitsbeoordeling van landbouwgronden in Nederland - indicatorset en systematiek versie 1.0. Wageningen Research, Rapport WPR-795. 34 blz. 1 fig; 2 tab; 23 ref.

Dit rapport is gratis te downloaden op https://doi.org/10.18174/498307

Het voorliggende rapport is bedoeld als synthese van beide methodieken tot een eerste versie 1.0 van de BLN en een robuuste systematiek. Het voornemen is om de BLN en de systematiek, inclusief meetmethoden en referentiewaarden, te gebruiken en door te ontwikkelen in de PPS Beter Bodembeheer. Daarnaast wordt de systematiek ook ingebracht in de European Joint Programming on Soil (EJPSoil) en wordt de BLN toegepast binnen het Klimaatprogramma Slim Landgebruik wat zich focust op het vergroten van de koolstofopslag in Nederlandse landbouwbodems.

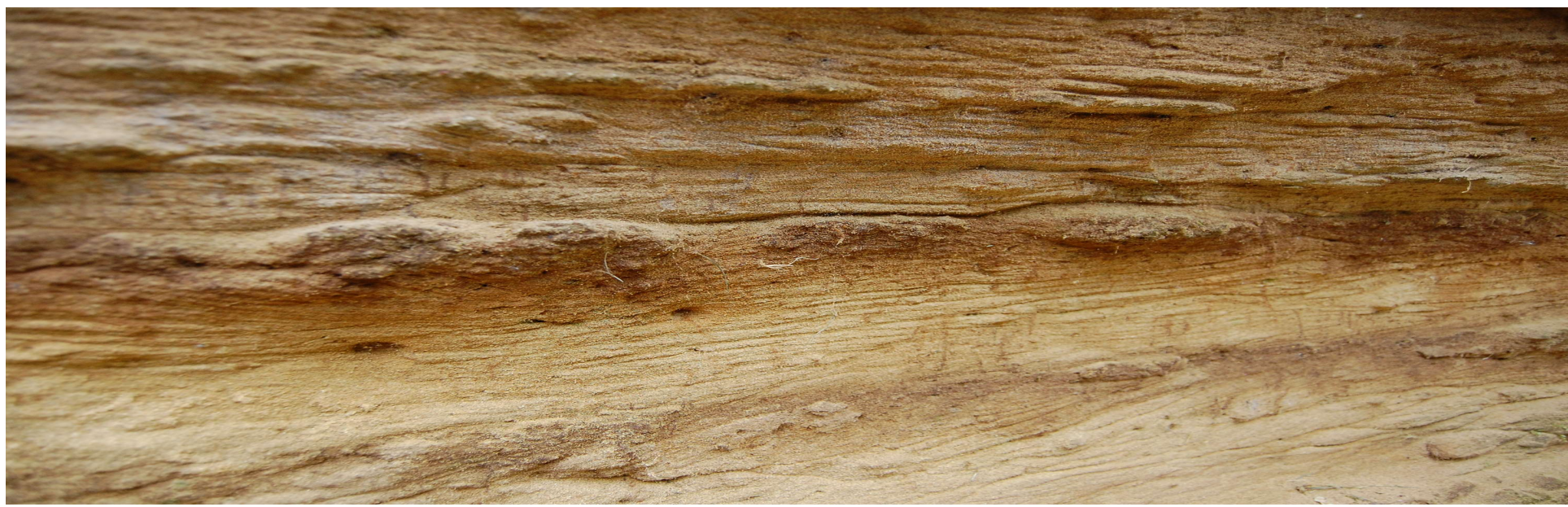




\section{begrippenlijst}

\section{Bodemeigenschap:}

Een kenmerk van een bodem dat indicatief kan zijn voor één of meer bodemfuncties.

\section{Bodemfunctie:}

De rol van de bodem in het vervullen van bepaalde doelstellingen. Onderscheid wordt gemaakt in verschillende type bodemfuncties: productiefunctie, draagfunctie, regulatiefunctie en informatiefunctie. In dit rapport hanteren we de indeling van Ten Berge \& Postma (2010).

\section{Bodemkwaliteit:}

De capaciteit van een bodem om onder wisselende omstandigheden de gewenste bodemfuncties in voldoende mate beschikbaar te hebben voor een combinatie van doelen zoals voedselproductie, efficiënte kringloop van voedingsstoffen en behoud van de biodiversiteit.

\section{Duurzaam beheer:}

Het gebruik van natuurlijke rijkdommen, waaronder bodems, water, dieren en planten, voor de productie van goederen om aan veranderende menselijke behoeften te voldoen, terwijl tegelijkertijd het lange termijn productieve potentieel van deze hulpbronnen en het onderhoud van hun milieufuncties worden gewaarborgd.

\section{Indicator:}

Een instrument (meting, dataset, model, expertsysteem) voor het kwantificeren van een (bodem)attribuut, en/of het verschaffen van kwantitatieve informatie over (deel-)processen van het systeem.

\section{Indicatorset:}

Het geheel van indicatoren, meetmethoden en referentiewaarden.

\section{NIRS:}

Near Infrared Spectroscopy. een indirecte meetmethoden waarbij reflectogrammen van infrarood licht worden gerelateerd aan de gewenste indicator. Een bepaald kenmerk van de bodem (b.v. textuur) wordt afgeleid aan de hand van een gereflecteerd infrarood licht spectrum wat wordt vergeleken met een klassieke meting.

\section{Referentiewaarde:}

De waarde waarmee een meetresultaat kan worden vergeleken in termen van hoog of laag, zonder oordeelsvorming in termen van goed of slecht.

\section{Streefwaarde:}

De waarde horende bij een beoordeling 'goed'.

Systematiek voor bodemkwaliteitsbeoordeling:

Een overkoepelende, samenhangende en logische aanpak voor afleiding van een indicatorset met streefwaarden en referentiewaarden voor bodemkwaliteitsbeoordeling van landbouwgronden, met gebruikmaking van onderbouwde en in het publieke domein gedocumenteerde kennis en gegevens.

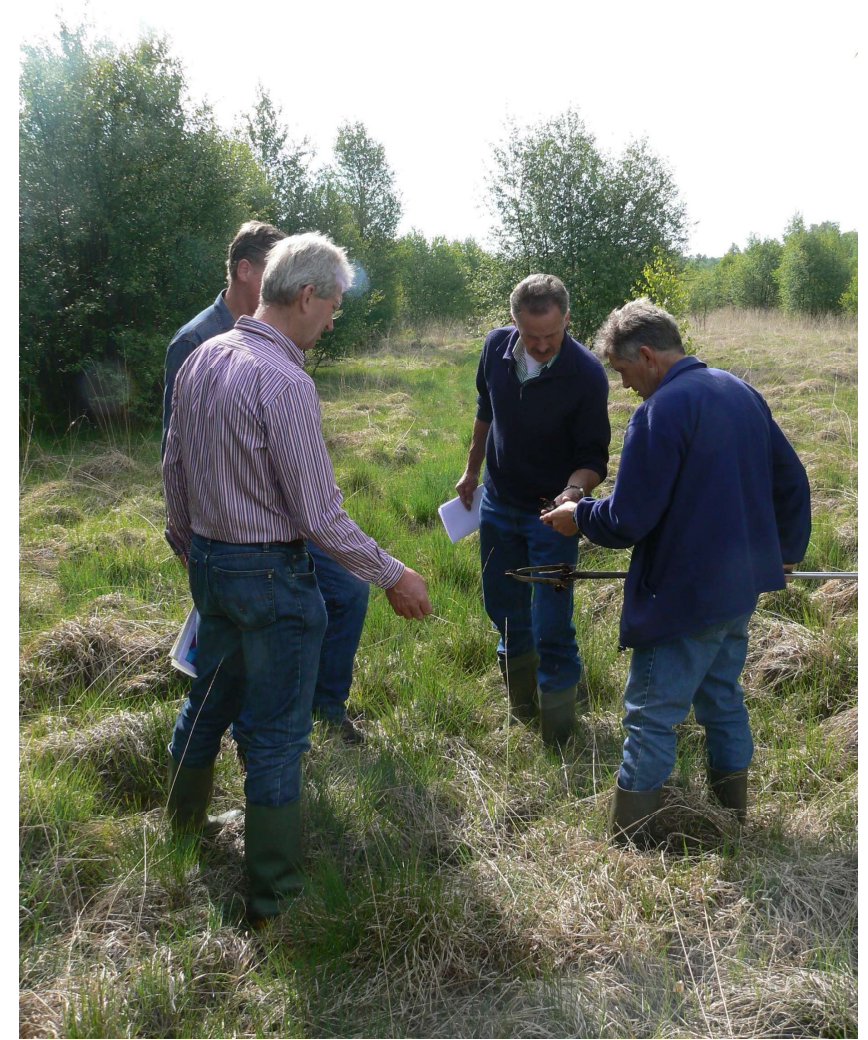




\section{Samenvatting}

De minister van Landbouw, Natuur en Voedselkwaliteit (LNV) beoogt dat alle landbouwbodems in Nederland in 2030 duurzaam worden beheerd. Om dat te kunnen realiseren is het onder meer nodig om vast te stellen hoe bodemkwaliteit kan worden gemeten en wat duurzaam beheer is. LNV heeft Wageningen University \& Research gevraagd om op basis van twee eerdere rapportages met een indicatorset te komen, gebaseerd op een robuuste systematiek, voor een eenduidige beoordeling van de bodemkwaliteit in landbouwgronden in Nederland. De indicatorset Bodemindicatoren voor Landbouwgronden in Nederland (BLN) bestaat uit 17 indicatoren en geeft, naast naam en eenheid van de indicator, aan of de indicator met klassiek en/of snelle en goedkope meetmethoden kan worden gemeten (Tabel 1). Het betreft een overkoepelende, samenhangende set van indicatoren voor de beoordeling van de bodemkwaliteit van landbouwgronden, die als basis kan dienen voor de selectie van indicatoren voor specifieke vormen van landgebruik, bodemtypen en doelen van de beoordeling.

Voor de selectie van indicatoren, meetmethoden en referentiewaarden is een robuuste systematiek opgezet in de vorm van een beslissingsondersteunend schema dat de gebruiker keuzemogelijkheden biedt die logisch volgen uit de voorgaande. Het concreet benoemen van alle gemaakte keuzen verbetert de uiteindelijke selectie en maakt deze transparant. De systematiek wil zo een handvat bieden aan partijen in het publieke en private domein, om zo te komen tot een eenduidige systematiek voor de beoordeling van de bodemkwaliteit in Nederland.
De gepresenteerde BLN versie is bruikbaar voor alle combinaties van bodemtypen en landgebruik in Nederland. De gepresenteerde streefwaarden zijn gebaseerd op de 'state-ofthe-art' binnen Nederland voor akkerbouw en grasland op zowel klei- als zandgrond. Gezien snelle ontwikkelingen in de technologie en instrumentarium zal op korte termijn actualisatie van de BLN nodig zijn. Dit zal in de PPS Beter Bodembeheer worden opgepakt. De drie belangrijkste aanbevelingen voor vervolgstappen zijn:

- Zorg voor een volledige uitwerking van referentiewaarden en streefwaarden voor alle grondsoorten en landgebruiksvormen in de landbouwsector van Nederland.

- Sluit wat landgebruik classificatie betreft aan bij de indeling die in het project CC-NL binnen de klimaatenvelop Slim Landgebruik.

- Pas indien noodzakelijk de indicatorset en meetmethoden aan voor andere grondsoorten en landgebruik. Kijk hierbij ook naar kosten van de indicatorset en draagvlak en uitvoerbaarheid bij laboratoria om het volgens het advies uit te voeren.

- Maak een uitbreiding c.q. koppeling met maatregelen mogelijk.

- Om het gebruik van de indicatorset en de systematiek te stimuleren is het zinvol om een applicatie te (laten) ontwikkelen, op basis van genoemde volledige beschrijving.

- Ontwikkel draagvlak voor indicatorset en systematiek bij zowel private en publieke partijen; dit rapport kan hierbij als vertrekpunt dienen voor een verkenning van mogelijke toepassingen in de praktijk.

Tabel 1: Geselecteerde indicatoren voor het bepalen van de bodemkwaliteit, gecombineerd uit Van den Elsen et al., (2019) en De Haan et al. $(2019)^{1}$.

\begin{tabular}{|c|c|c|c|c|c|}
\hline & Nr & Indicator & Eenheid & Klassieke meetmethode & $\begin{array}{l}\text { Snelle, goedkopere } \\
\text { meetmethode? }\end{array}$ \\
\hline \multirow{3}{*}{$\begin{array}{l}4 \\
0 \\
5 \\
0 \\
0\end{array}$} & 1 & Organische stofgehalte en koolstofgehalte & $\%$ & Gloeiverlies en Dumas & NIRS \\
\hline & 2 & Stabiele fractie organische stof & $\%$ & $\begin{array}{l}\text { Oxidatie in permanganaat } \\
\text { (POXC) }\end{array}$ & n.b. \\
\hline & 3 & Heet water extraheerbare koolstof (HWC) & $\mathrm{mg} \mathrm{kg}^{-1}, \mathrm{~g} \mathrm{ha}^{-1}$ & Extractie in heet water & n.b. \\
\hline \multirow{5}{*}{$\frac{5}{\hat{U}}$} & 4 & Watervasthoudend vermogen & $\%, \mathrm{~mm}$ & Zandbak/drukpan & o.b.v. textuur + OS \\
\hline & 5 & Aggregaatstabiliteit & - & Natte zeefmethode & n.b. \\
\hline & 6 & Textuur & $\%$ & Pipetmethode & NIRS \\
\hline & 7 & Indringingsweerstand & Mpa & Penetrometer & \\
\hline & 8 & Droge bulkdichtheid & $\mathrm{kg} \mathrm{m}^{-3}$ & Massa na drogen $105^{\circ} \mathrm{C}$ & Berekend uit OS\% \\
\hline \multirow{5}{*}{$\begin{array}{l}\frac{5}{\mathcal{n}} \\
\frac{\mathrm{n}}{\mathrm{U}} \\
\text { U }\end{array}$} & 9 & Zuurgraad $(\mathrm{pH})$ & - & Extractie in $\mathrm{CaCl}_{2}$ & \\
\hline & 10 & N-totaal & $\mathrm{g} \mathrm{kg}^{-1}, \mathrm{~kg} \mathrm{ha}^{-1}$ & Kjeldahl & NIRS \\
\hline & 11 & Potentieel mineraliseerbare stikstof (PMN) & $\mathrm{mg} \mathrm{kg}^{-1}, \mathrm{~g} \mathrm{ha}^{-1}$ & Anaerobe incubatie & NIRS \\
\hline & 12 & Fosfaatstatus 3 & $\begin{array}{l}\text { mg } 100 \mathrm{~g}^{-1}, \\
\mathrm{~g} \mathrm{~kg}^{-1}, \mathrm{~kg} \mathrm{ha}^{-1} \\
\mathrm{mg} 100 \mathrm{ml}^{-1}\end{array}$ & $\begin{array}{l}\text { Extractie in ammoniumlactaat- } \\
\text { azijnzuur, } \mathrm{CaCl}_{2} \text { resp. water }\end{array}$ & \\
\hline & 13 & Kalistatus ${ }^{3}$ & $\begin{array}{l}\mathrm{mg} 100 \mathrm{~g}^{-1} \mathrm{mmol}^{+} / \mathrm{kg} \\
\mathrm{g} \mathrm{kg}^{-1}, \mathrm{~kg} \mathrm{ha}^{-1}\end{array}$ & Extractie in $\mathrm{HCl}$ en oxaalzuur & NIRS + Extractie in $\mathrm{CaCl}_{2}$ \\
\hline \multirow{3}{*}{$\begin{array}{l}\frac{5}{4} \\
\frac{\hat{n}}{5} \\
\frac{0}{0}\end{array}$} & 14 & $\begin{array}{l}\text { Aaltjes diversiteit en aantallen (incl. } \\
\text { plantparasitaire aaltjes) }\end{array}$ & $\begin{array}{l}\text { Aantal taxa } \\
\# 100 \mathrm{ml}^{-1} \text { grond }\end{array}$ & Microscopie & PCR \\
\hline & 15 & Bacterie- en schimmelbiomassa & $\mu \mathrm{g} \mathrm{kg}^{-1}$ & PLFA & NIRS \\
\hline & 16 & Regenwormen aantallen en diversiteit & $\# \mathrm{~m}^{-2}, \mathrm{~kg} \mathrm{~m}^{-2}$ & Visueel & n.b. \\
\hline$\frac{q}{\alpha}$ & 17 & $\begin{array}{l}\text { Visuele beoordeling (fysisch-chemisch- } \\
\text { biologisch) }\end{array}$ & Divers & Visueel & n.b. \\
\hline
\end{tabular}

${ }^{1}$ De set is opgesteld vanuit bodemvruchtbaarheid / bemestingsoogpunt.

2 n.b. niet bekend, maar wel wenselijk. Wanneer de cel in de laatste kolom leeg is, is de klassieke methode 'snel \& goedkoop' en is er geen noodzaak voor een alternatieve meetmethode.

3 De aard van de indicator kan per sector verschillen, bijvoorbeeld voor P: in de melkveehouderij P-voorraad \& P-beschikbaar, en voor de akkerbouw Pw; voor de akkerbouw zou 'Nmin in het najaar' als indicator kunnen worden opgenomen. 


\section{Inleiding}

\section{Aanleiding}

De aanleiding van dit rapport is de publieke en private wens om te komen tot één eenduidige systematiek voor het bepalen van de bodemkwaliteit in Nederland en het bestaan van verschillende indicatorsets vanuit WUR voor het beoordelen van bodemkwaliteit in de landbouw (van den Elsen et al. 2019; de Haan et al. 2019). In bijlage 1 is de achtergrond van beide indicatorsets beschreven. Het Ministerie van Landbouw, Natuur en Voedselkwaliteit (LNV) heeft WUR gevraagd om op basis van beide studies te komen met een synthese voor een eenduidige, robuuste, wetenschappelijk onderbouwde indicatorset voor het meten van bodemkwaliteit.

De opgave voor het Ministerie van LNV is dat in 2030 alle landbouwbodems in Nederland duurzaam beheerd worden (Ministerie van LNV, 2019). Om dit te realiseren is het onder andere nodig om te bepalen wat een duurzaam beheer is. Om de bodem aan alle gebruikseisen te laten voldoen is een universele toets van de bodemkwaliteit essentieel belang. De indicatoren, meetmethoden, gevoeligheid van meetmethoden, referentiewaarden en achterliggende systematiek worden in dit document benoemd en beknopt beschreven. Voor een uitgebreide beschrijving en verantwoording wordt verwezen naar beide achterliggende studies.

\section{Doel}

Het primaire doel van dit rapport is aangeven met welke indicatoren en streefwaarden de bodemkwaliteit van landbouwpercelen in Nederland voldoende wetenschappelijk onderbouwd kan worden vastgesteld. Duurzaam bodembeheer gaat over alle ecosysteemdiensten van landbouwbodems. Dus naast landbouwproductie ook over aspecten als klimaatregulatie, waterregulatie en biodiversiteit. De gepresenteerde indicatorset Bodemindicatoren voor Landbouwgronden in Nederland (BLN) 1.0 is bruikbaar voor alle combinaties van bodemtypen en landgebruik in Nederland.

Bij het opstellen van dit rapport werd duidelijk dat het breed vaststellen van bodemkwaliteit een zeer lastige opgave is en dat meer aandacht besteed moet worden aan het doel en de context waarom gebruikers bodemmetingen uitvoeren.

Hiervoor is een overkoepelende systematiek ontwikkeld om afhankelijk van doel en context tot de juiste set aan indicatoren met gekoppelde meetmethoden te komen.

\section{Afbakening}

De BLN bevat een samenhangende set van indicatoren en is geschikt als basis voor mogelijke uitwerking naar sectoren (landgebruik en bodemtype) en doelen. De getalsmatige invulling van streef- en referentiewaarden is beperkt tot de akkerbouw en grasland op zand- en kleigronden.

\section{Leeswijzer}

Dit document beschrijft de selectie van indicatoren, de beschikbare meettechnieken voor het meten van de waarde van deze indicatoren en referentiewaarden voor een bodemtype/gewas combinatie met overwegingen (hoofdstuk 2) en de achterliggende systematiek voor selectie van indicatoren en meetmethoden (hoofdstuk 3). Het rapport sluit af met conclusies en aanbevelingen voor vervolgactiviteiten om de systematiek verdere te ontwikkelingen (hoofdstuk 4). In de bijlagen 2 en 3 worden enkele operationele aspecten genoemd die van belang zijn voor verdere uitwerking van de systematiek.

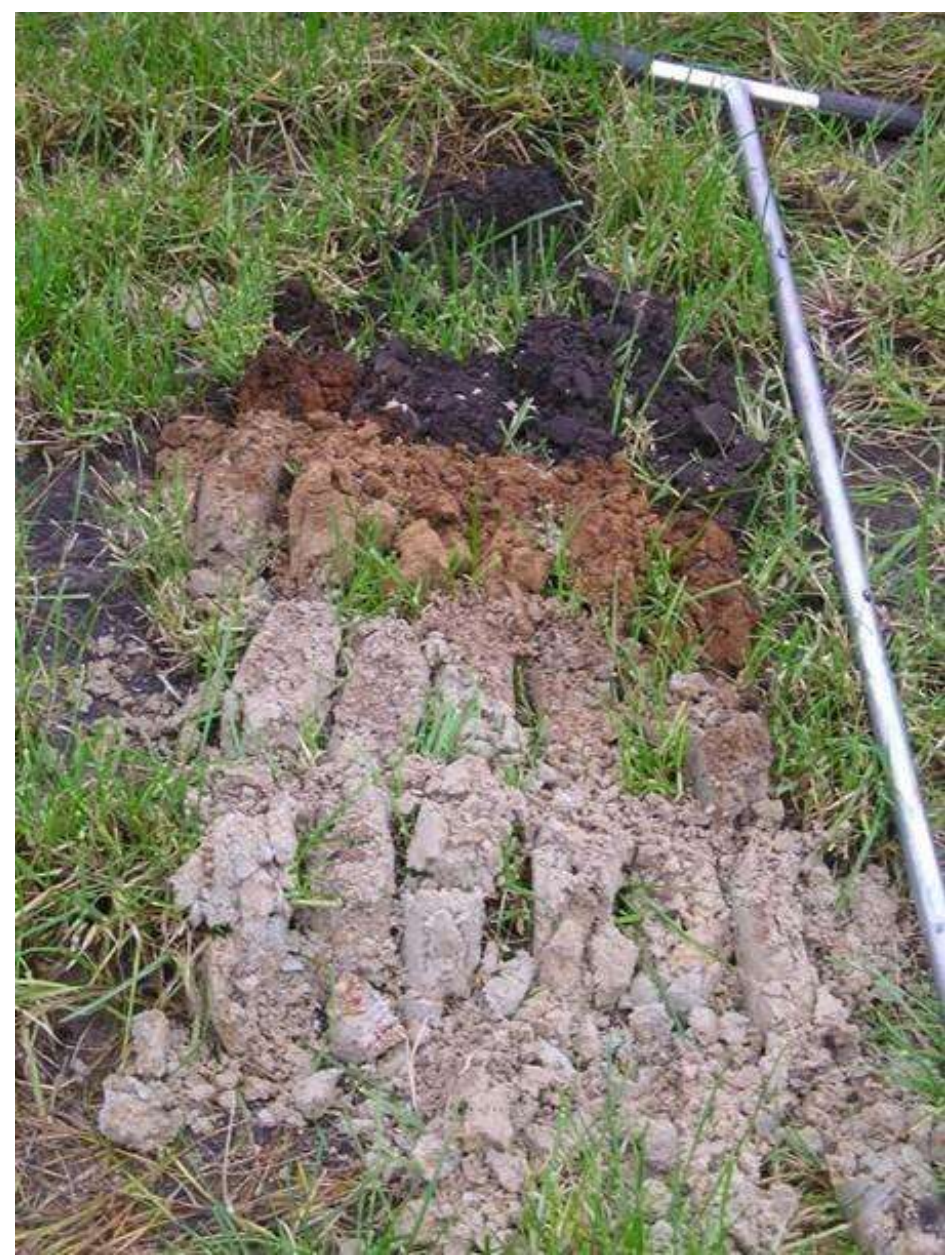




\section{BLN versie 1.0 voor het beoordelen van de bodemkwaliteit voor landbouw}

\subsection{Indicatoren en meetmethoden}

\section{Indicatoren}

Zoals al in de inleiding is aangegeven is de in dit document gepresenteerde indicatorset een combinatie van twee eerder, onafhankelijk van elkaar, ontwikkelde indicatorsets. In de rapporten over deze indicatorsets staan achtergronden over de keuze van deze indicatoren beschreven (van den Elsen et al. 2019; de Haan et al. 2019). In deze rapporten is ook de methode waarop omgegaan kan worden met variatie binnen een perceel opgenomen, en dit wordt dus in dit rapport niet in detail besproken. De overeenkomsten tussen beide indicatorsets waren groot, en daarmee was het vrij gemakkelijk om tot een gecombineerde lijst te komen. De in Tabel 1 gepresenteerde lijst is een wetenschappelijk verantwoorde indicatorset die de basis vormt om de kwaliteit van de Nederlandse landbouw bodems integraal, voor verschillende doelen, vast te stellen. In deze paragraaf worden de meetmethoden verder toegelicht; streef- en referentiewaarden van de indicatoren worden in paragraaf 2.2 uitgewerkt.

\section{Meetmethoden voor het meten van indicatorwaarden}

Om te komen tot een gefundeerde selectie van meetmethoden hebben we gebruik gemaakt van de volgende criteria; de meetmethode moet:

- voldoende nauwkeurig en precies zijn om verandering van de indicator door management van de boer binnen grenzen te kunnen detecteren (uitgezonderd textuur).

- zo goedkoop mogelijk zijn binnen de bij punt 1 gestelde nauwkeurigheids- en precisiegrenzen.

- snel en praktisch uit te voeren zijn (in veld of lab).

- zo robuust mogelijk zijn (robuust = onafhankelijk van invloeden van andere omstandigheden).

In de (wetenschappelijke) literatuur is een veelheid aan methoden te vinden en voor alle geselecteerde indicatoren zijn in principe meerdere meetmethoden beschikbaar. Dit kunnen klassieke laboratorium- en/of veldmethoden zijn, of moderne, snellere en goedkopere meetmethoden die veelal gebaseerd zijn op grootschalige statistische

gegevensverwerking. Bijna alle klassieke meetmethoden zijn directe methoden, waarbij de grootheid waarin we geïnteresseerd zijn direct worden gemeten.

Voor de snelle en goedkope meetmethoden wordt veel gebruik gemaakt van Near Infrared Spectroscopy (NIRS) methoden. NIRS is een indirecte meetmethoden waarbij reflectogrammen van infrarood licht worden gerelateerd aan de gewenste indicator. Infraroodspectroscopie wordt veel gebruikt, zowel in onderzoek als industrie, omdat het een eenvoudige en betrouwbare methode is om een stof te herkennen, of de zuiverheid en/of samenstelling van een monster vast te stellen. Een bepaald kenmerk van de bodem (b.v. textuur) wordt afgeleid aan de hand van een gereflecteerd infrarood licht spectrum wat wordt vergeleken met een klassieke meting. Een NIRS-bepaling wordt nauwkeuriger en betrouwbaarder naarmate meer reflectogrammen worden vergeleken met klassieke bepalingen.
Een ander voorbeeld van een moderne snelle meetmethoden is high throughput DNA/RNA sequencing. Deze methode kan worden ingezet om bodemorganismen te meten. De methode biedt een goede betrouwbaarheid en nauwkeurigheid, maar stelt voorwaarden aan de beschikbaarheid van 'libraries' van bekende sequenties van organismen. Overigens moeten snelle en goedkope meetmethoden gezien worden in relatie tot hun klassieke methode. Prijs en snelheid van snelle en goedkope meetmethoden kunnen onderling sterk verschillen.

Tabel 1 geeft een overzicht van de beschikbare meettechnieken voor de geselecteerde indicatoren (voor de protocollen van de meetmethoden wordt verwezen naar Van den Elsen et al., (2019) en De Haan et al. (2019)). Er is een klassieke meetmethode opgenomen, veelal gekenmerkt door grote nauwkeurigheid en betrouwbaarheid van het vaststellen van de indicator. Daarnaast is, indien aanwezig, een alternatieve meetmethode benoemd waarmee de indicator sneller en/of goedkoper bepaald kan worden.

Voor een aantal chemische indicatoren is geen alternatieve meetmethode noodzakelijk, de klassieke methode is snel en goedkoop. Voor een aantal biologische indicatoren ontbreekt nog een snelle meetmethode. Bij een aantal indicatoren zonder een snelle en goedkope methode is mogelijk de NIRS methode toepasbaar maar nog niet ontwikkeld of nog in een experimenteel stadium, bijvoorbeeld voor de diversiteit en aantallen schimmels. Vanuit nauwkeurigheid en betrouwbaarheid hebben de klassieke methoden vooralsnog de voorkeur.

De iBLN is een overkoepelende, samenhangende set, nodig voor de beoordeling van de bodemkwaliteit van Nederlandse landbouwgronden. De context specifieke selectie van indicatoren en meetmethoden kan variëren met andere vormen van landgebruik, bodemtypes en doel(-en) van de meting. Wat betreft de meetmethoden kan ook worden gekozen voor niet in de tabel genoemde methoden, zoals sensortechnologie, beschikbare databronnen en/of modelberekeningen. Hierbij kan het kostenaspect een rol spelen. 
Tabel 1: Geselecteerde indicatoren voor het bepalen van de bodemkwaliteit, gecombineerd uit Van den Elsen et al., (2019) en De Haan et al. $(2019)^{1}$

\begin{tabular}{|c|c|c|c|c|c|}
\hline & Nr & Indicator & Eenheid & Klassieke meetmethode & $\begin{array}{l}\text { Snelle, goedkopere } \\
\text { meetmethode? }\end{array}$ \\
\hline \multirow{3}{*}{$\begin{array}{l}4 \\
0 \\
\text { ज़ } \\
0 \\
0\end{array}$} & 1 & Organische stofgehalte en koolstofgehalte & $\%$ & Gloeiverlies en Dumas & NIRS \\
\hline & 2 & Stabiele fractie organische stof & $\%$ & $\begin{array}{l}\text { Oxidatie in permanganaat } \\
\text { (POXC) }\end{array}$ & n.b. \\
\hline & 3 & Heet water extraheerbare koolstof (HWC) & $\mathrm{mg} \mathrm{kg}^{-1}, \mathrm{~g} \mathrm{ha}^{-1}$ & Extractie in heet water & n.b. \\
\hline \multirow{5}{*}{$\frac{5}{5}$} & 4 & Watervasthoudend vermogen & $\%, \mathrm{~mm}$ & Zandbak/drukpan & o.b.v. textuur + OS \\
\hline & 5 & Aggregaatstabiliteit & - & Natte zeefmethode & n.b. \\
\hline & 6 & Textuur & $\%$ & Pipetmethode & NIRS \\
\hline & 7 & Indringingsweerstand & Mpa & Penetrometer & \\
\hline & 8 & Droge bulkdichtheid & $\mathrm{kg} \mathrm{m}^{-3}$ & Massa na drogen $105^{\circ} \mathrm{C}$ & Berekend uit OS\% \\
\hline \multirow{5}{*}{ 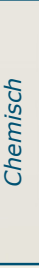 } & 9 & Zuurgraad $(\mathrm{pH})$ & - & Extractie in $\mathrm{CaCl}_{2}$ & \\
\hline & 10 & N-totaal & $\mathrm{g} \mathrm{kg}^{-1}, \mathrm{~kg} \mathrm{ha}^{-1}$ & Kjeldahl & NIRS \\
\hline & 11 & Potentieel mineraliseerbare stikstof (PMN) & $\mathrm{mg} \mathrm{kg}^{-1}, \mathrm{~g} \mathrm{ha}^{-1}$ & Anaerobe incubatie & NIRS \\
\hline & 12 & Fosfaatstatus 3 & $\begin{array}{l}\text { mg } 100 \mathrm{~g}^{-1}, \\
\mathrm{~g} \mathrm{~kg}^{-1}, \mathrm{~kg} \mathrm{ha}^{-1} \\
\mathrm{mg} 100 \mathrm{ml}^{-1}\end{array}$ & $\begin{array}{l}\text { Extractie in ammoniumlactaat- } \\
\text { azijnzuur, } \mathrm{CaCl}_{2} \text { resp. water }\end{array}$ & \\
\hline & 13 & Kalistatus ${ }^{3}$ & $\begin{array}{l}\mathrm{mg} 100 \mathrm{~g} \mathrm{~g}^{-1} \mathrm{mmol}^{+} / \mathrm{kg} \text {, } \\
\mathrm{g} \mathrm{kg}^{-1}, \mathrm{~kg} \mathrm{ha}^{-1}\end{array}$ & Extractie in $\mathrm{HCl}$ en oxaalzuur & NIRS + Extractie in $\mathrm{CaCl}_{2}$ \\
\hline \multirow{3}{*}{$\begin{array}{l}\frac{1}{0} \\
\frac{-1}{0} \\
\frac{0}{0} \\
\frac{0}{0}\end{array}$} & 14 & $\begin{array}{l}\text { Aaltjes diversiteit en aantallen (incl. } \\
\text { plantparasitaire aaltjes) }\end{array}$ & $\begin{array}{l}\text { Aantal taxa } \\
\# 100 \mathrm{ml}^{-1} \text { grond }\end{array}$ & Microscopie & PCR \\
\hline & 15 & Bacterie- en schimmelbiomassa & $\mu \mathrm{g} \mathrm{kg}{ }^{-1}$ & PLFA & NIRS \\
\hline & 16 & Regenwormen aantallen en diversiteit & $\# \mathrm{~m}^{-2} \mathrm{~kg} \mathrm{~m}^{-2}$ & Visueel & n.b. \\
\hline$\frac{\pi}{\pi}$ & 17 & $\begin{array}{l}\text { Visuele beoordeling (fysisch-chemisch- } \\
\text { biologisch) }\end{array}$ & Divers & Visueel & n.b. \\
\hline
\end{tabular}

${ }^{1}$ De set is opgesteld vanuit bodemvruchtbaarheid / bemestingsoogpunt.

2 n.b. niet bekend, maar wel wenselijk. Wanneer de cel in de laatste

kolom leeg is, is de klassieke methode 'snel \& goedkoop' en is er geen

noodzaak voor een alternatieve meetmethode.

${ }^{3}$ De aard van de indicator kan per sector verschillen, bijvoorbeeld voor $\mathrm{P}$ : in de melkveehouderij P-voorraad \& P-beschikbaar, en voor de akkerbouw

Pw; voor de akkerbouw zou 'Nmin in het najaar' als indicator kunnen worden opgenomen.

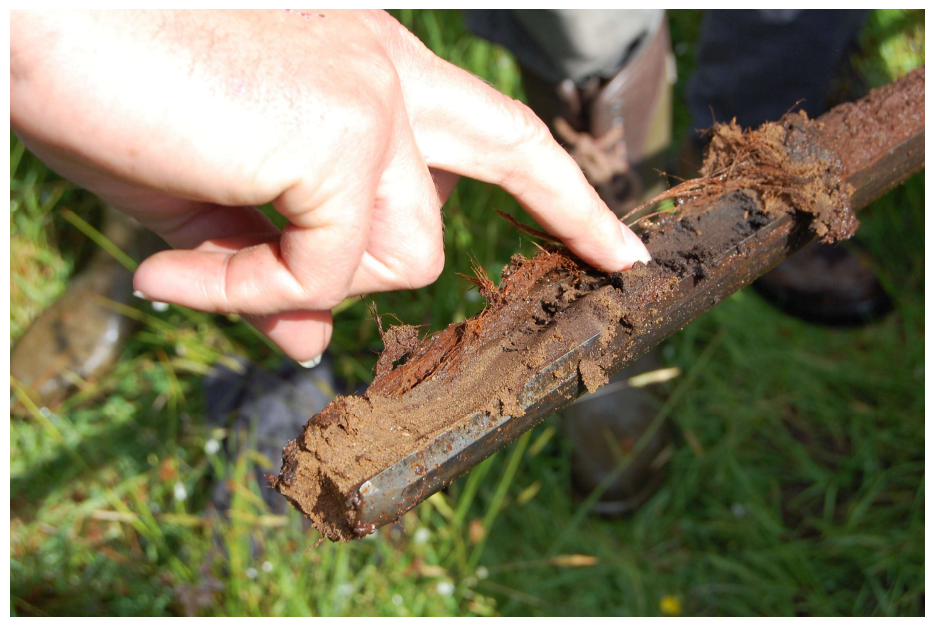

\subsection{Referentiewaarden}

In tabel 2 zijn referentiewaarden opgenomen voor akkerbouw en gras op klei en zandgrond. Andere landgebruiken en grondsoorten zijn vanwege gebrek aan tijd niet meegenomen. Bij het afleiden van referentiewaarden is zoveel als mogelijk gebruikt gemaakt van de volgende bronnen:

1 . Bodembiologische Indicator (BOBI) en Referenties Biologische Bodemkwaliteit (RBB) (statistisch, vooral biologische indicatoren, Rutgers et al., 2007).

2. Eurofins Agro (vooral chemische indicatoren, gebaseerd op PhD-theses (o.a. Van Erp, 2002; Van Rotterdam-Los, 2010).

1. Handboek Bodem en Bemesting

(www.handboekbodemenbemesting.nl) en Adviesbasis

Grasland en voedergewassen (www.bemestingsadvies.nl). 2. Plantparasitaire aaltjes: Aaltjesschema.nl.

Voor referentiewaarden van snelle en goedkope

meetmethoden zoals NIRS is geen documentatie voorhanden, maar deze waarden zijn op aanvraag beschikbaar bij Eurofins Agro (pers. mededeling Dr. A Reijneveld 15 juli 2019). De specifieke getallen kunnen in een later stadium worden opgenomen in de systematiek. 
Tabel 2: Referentiewaarden voor de landgebruik-bodem combinaties akkerbouw op klei, akkerbouw op zand, melkveehouderij op klei en melkveehouderij op zand. N.b. betekent niet beschikbaar. Voor de chemische indicatoren afkomstig uit het Handboek Bodem en Bemesting en de Adviesbasis Grasland en Voedergewassen zijn de genoemde referentie waarden ook streefwaarden.

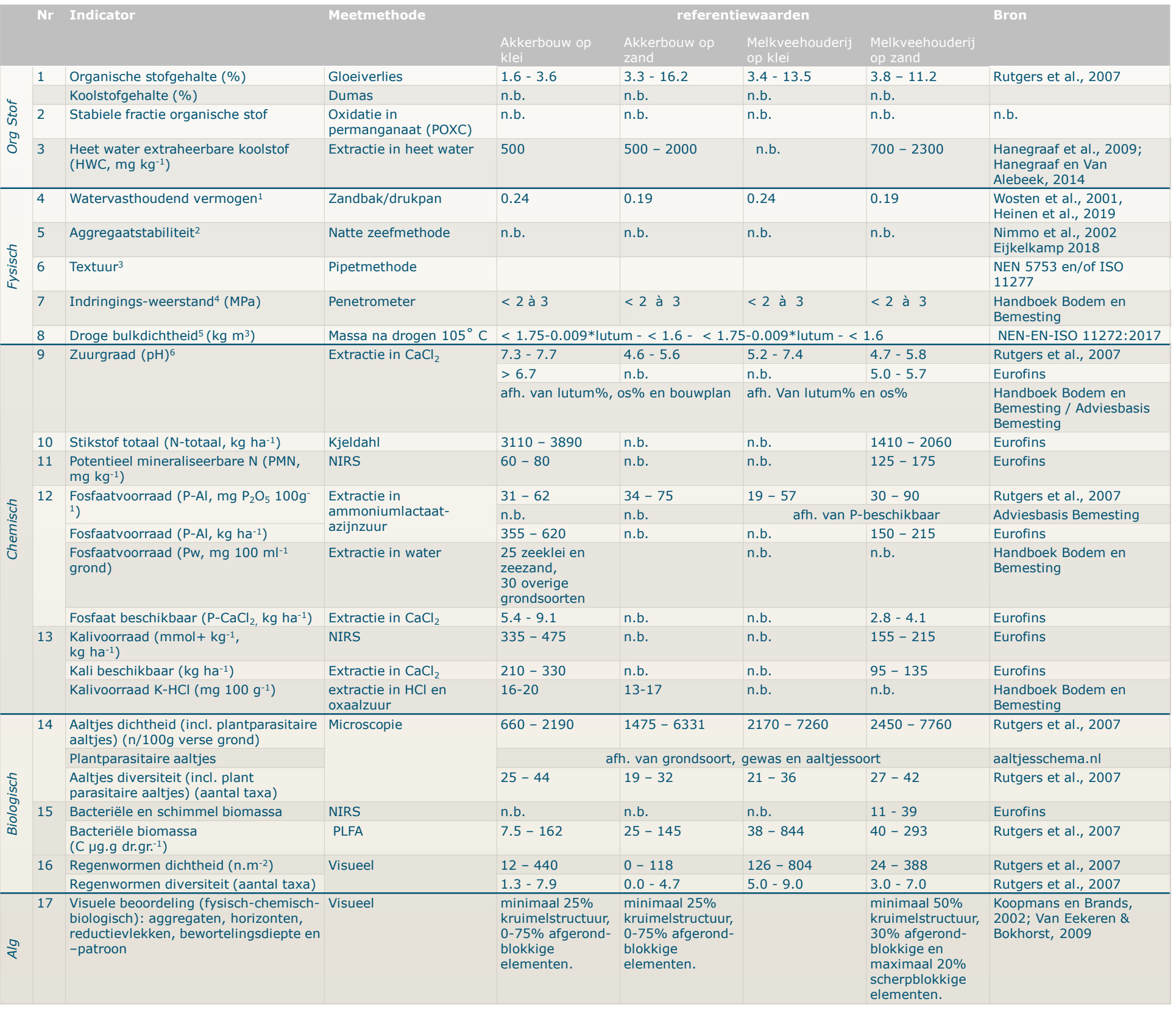

${ }^{1}$ Het watervasthoudend vermogen van een bodem is het verschil van volumetrisch vochtgehalte tussen drukhoogten pF 2.0 en $\mathrm{pF} 4.2$ op de waterretentiekarakteristiek ( $\mathrm{pF}$ curve). Dit watervasthoudend vermogen is afhankelijk van textuur en structuur van een bodem. Er moet onderscheid worden gemaakt tussen bodemtypen; hier zijn de waarden gegeven voor zand en klei. De watervoorraad in de wortelzone 0 -30cm is het watervasthoudend vermogen uit de tabel $\mathrm{wVv} * 30[\mathrm{~cm}]$ of $\mathrm{wVv} * 30 * 10[\mathrm{~mm}]$

2 De aggregaat stabiliteit is het percentage aggregaten wat overblijft na onderwerping aan de natte zeefmethode [Nimmo, 2002 of Eijkelkamp, 2018] of mini regenvalsimulator (Moebius-Clune, 2016: pp44). Er zijn voor Nederlandse gronden nog niet voldoende meetgegevens beschikbaar om hier referentiewaarden voor te geven.

3 Textuur is een kenmerk van de bodem en dient als hulpvariabele bij de interpretatie van andere indicatoren. De textuur van een bodem is een vaststaand geven welke niet beïnvloedbaar is door management. Daarom worden geen referentiewaarden gegeven.

${ }^{4}$ De grenswaarde voor de indringingsweerstand is sterk afhankelijk van: a) vochtgehalte van de bodem, b) vermogen van een gewaswortel om door te dringen in het bodemprofiel en daardoor gewasafhankelijk vandaar dat een waarde tussen 2 en 3 wordt gegeven.

5 De gemeten droge bulkdichtheid is een absolute maat voor de dichtheid van de bodem. Deze eigenschap is soms ook nodig om gemeten andere (biologische) indicatoren om te rekenen naar de juiste eenheden. Het meten van de bulkdichtheid is tevens van belang indien bij het meten van de indringingsweerstand het vermoeden bestaat dat (een deel van) het bodemprofiel is verdicht. Voor gronden met lutum < $16.7 \%$ (zand, en lichte + matig zware zavel) geldt dat de kritieke dichtheid $1.6 \mathrm{~g} / \mathrm{cm} 3$ is; voor gronden met lutum $>=16.7 \%$ (zware zavel- en kleigronden) geldt dat de kritieke dichtheid (1.75-0.009*lutum) g/cm3 is. Beoordeling: van den Elsen et. al. sectie 2.4.2.: voor gronden met lutum < $16.7 \%$ (zand, en lichte + matig zware zavel) geldt dat de kritieke dichtheid $1.6 \mathrm{~g} / \mathrm{cm} 3$ is; voor gronden met lutum $>=16.7 \%$ (zware zavel- en kleigronden) geldt dat de kritieke dichtheid $(1.75-0.009 *$ lutum $) \mathrm{g} / \mathrm{cm} 3$ is.

6 Merk op dat de voorkeursmethode extractie in $\mathrm{CaCl}_{2}$ is; een omrekening is noodzakelijk. 


\subsection{Overwegingen bij de selectie van indicatoren, meetmethoden en referentiewaarden}

Het meten van bodemkwaliteit is bepaald geen sinecure. Onder onderzoekers is er vaak veel discussie over de keuze van de indicatoren en de waarde van de uitslag. Daarnaast is van veel indicatoren de functie en de werking in de bodem op hoofdlijnen weliswaar bekend, maar ontbreekt de exacte betekenis. Dit geldt vooral voor biologische indicatoren. Weinig is bekend van de samenhang tussen afzonderlijke indicatoren, zeker tussen fysische, chemische en biologische indicatoren.

Om te komen tot een zo robuust mogelijk systematiek voor het beoordelen van de bodemkwaliteit, moet bij het meten en bij de interpretatie van de meetwaarden met een aantal zaken rekening worden gehouden. De belangrijkste hiervan zijn: betrouwbaarheid van de gebruikte meettechniek, afhankelijkheid van metingen voor omgevingsomstandigheden, het kostenaspect en de afzonderlijke èn de integrale beoordeling van de metingen. Gezien het ontbreken van informatie over de betrouwbaarheid en de referentiewaarden bij veel van de snelle goedkope meetmethoden, zijn deze nog ongeschikt voor breed gebruik.

\section{Betrouwbaarheid van de meettechniek en kosten}

Een overzicht van de meetmethoden die zijn meegewogen is gegeven in Bijlage 2. Voor de meeste indicatoren zijn zowel klassieke (bijvoorbeeld gloeiverlies voor bepaling van het OS\%) als moderne meetmethoden (bijvoorbeeld Near Infrared Spectoscropy (NIRS) voor bepaling van de beschikbare fosfaat, en/of high throughput sequencing van bijvoorbeeld DNA en vetzuren beschikbaar. Soms kan een indicator ook langs andere weg kan worden bepaald, bijvoorbeeld via databronnen of modelberekeningen. Hierbij hebben de volgende overwegingen een rol gespeeld:

1. Aan het gebruik van NIRS kleven bezwaren. In de eerste plaats is NIRS geen directe, maar een afgeleide meting, doordat de afgelezen waarde ('reading') statistisch wordt vergeleken met een 'schaduwdataset' van klassieke metingen. De nauwkeurigheid van NIRS hangt af van de omvang van de schaduwdataset. In de tweede plaats is er beperkt begrip van het verband tussen de reading en de indicator die ermee wordt uitgedrukt. Tegenover deze bezwaren staat dat NIRS-metingen snel en goedkoop zijn, en betrouwbaar zijn als een voldoende omvangrijke schaduw dataset wordt gebruikt.

2. High throughput sequencing biedt een goede betrouwbaarheid en nauwkeurigheid, maar stelt voorwaarden aan de beschikbaarheid van 'libraries' van bekende sequenties van organismen.

Voor met name de snelle en goedkope meetmethoden, maar ook voor enkele klassieke methoden is validatie hard nodig.

\section{Afhankelijkheid van indicatoren voor omgevingsomstandigheden en weersgeschiedenis} Sommige van de in Tabel 1 genoemde indicatoren zijn gevoelig voor omgevingsfactoren. Dit betreft voornamelijk de afhankelijkheid van de indicatoren voor temperatuur, (bodem)vochtgehalte ten tijde van de (veld)meting en/of monstername in het veld. Bovendien speelt de weersgeschiedenis van het perceel voor de monstername of meting een grote rol. Zo kan de droge zomer van 2018 nu (2019) nog doorwerken in bodemkenmerken. Bodemtype en gewas zijn uiteraard ook van invloed op de interpretatie van de meetwaarde. In Bijlage 2 wordt in de kolom

'Afhankelijkheid' weergegeven wat de gevoeligheid van de betreffende parameter is voor temperatuur, vochtgehalte van de bodem, het weer, het bodemtype en het gewas. Een robuuste systematiek voor het bepalen van bodemkwaliteit minimaliseert deze factoren en/of houdt er rekening mee. Hoe dit kan worden opgepakt, wordt in Bijlage 2 verder uitgelegd.

\section{Classificatie en beoordelen van de bodemkwaliteit} Voor een bruikbare indicatorset is het van belang om de uitkomsten ook goed te representeren.

Meetwaarden van de geselecteerde indicatoren zeggen de meeste niet-wetenschappers weinig of niets. Ze zijn in verschillende eenheden waarbij gebruikers vaak geen of weinig gevoel bij hebben wat goed en wat slecht is. Om voor alle gebruikers van een systeem voor bodemkwaliteit dat door een breed werkveld geaccepteerd en gedragen wordt, is het belangrijk dat de meetwaarden ook worden vertaald in een stelsel wat voor iedereen eenduidig te begrijpen is. Men kan denken aan een scoresysteem 0-100 of een classificatie 'slecht', 'matig', 'goed', of een systeem met meer verschillende klassen. Hoe fijner het classificatiesysteem is, hoe beter kleine veranderingen (verbeteringen) kunnen worden aangetoond in vervolgmetingen. Nog beter dan afzonderlijke klassen, hoe verfijnd ook, kan een (score)functie veranderingen aangeven. Dergelijke systemen worden in Bijlage 3 beschreven. Belangrijk aandachtspunt is dat classificatie- en beoordelingssystemen subjectief zijn.

\section{Referentiewaarden en streefwaarden}

Streefwaarden geven een duidelijk oordeel of een gemeten waarde goed of fout is. Ze zijn daarom per definitie subjectief. Streefwaarden kunnen afgeleid zijn uit onderzoek over wat gewenste waarden zijn maar ook uit wet en regelgeving. Voorwaarde voor opname binnen de systematiek is dat de streefwaarden zijn gebaseerd op wetenschappelijk gedocumenteerd onderzoek. Referentiewaarden zijn waarden waarmee het resultaat van een meting kan worden vergeleken om zo te komen tot interpretatie indien geen streefwaarde bekend is. Het betreft waarden die uit een groot aantal veldwaarnemingen komen en de mogelijke range aangeven. Het feit dat in het veld is gemeten wil dus niet zeggen dat deze referentiewaarden de gewenste waarde aangeven. Er zijn verschillende typen referentiewaarden mogelijk: statistisch afgeleid, regiogemiddelden, range van gevonden meetwaarden, vergelijking tussen percelen van goede en matige bodemkwaliteit, vergelijking van meetwaarden tussen jaren, etc.

Voor de beoordeling van bodemkwaliteit heeft het gebruik van streefwaarden de voorkeur boven referentiewaarden. In tabel 2 zijn voornamelijk referentiewaarden opgenomen. De referentiewaarden hebben vooral betrekking op de biologische en fysische indicatoren uit onder andere BOBI en RBB, die bedoeld zijn als afspiegeling van een duurzaam bedrijfssysteem. Voor de chemische indicatoren zijn de genoemde referentie waarden ook streefwaarden, afkomstig uit het Handboek Bodem en Bemesting en de Adviesbasis Grasland en Voedergewassen. 


\section{Opzet van een robuuste systematiek}

\subsection{Aanleiding}

Voorgaande hoofdstukken presenteren een indicatorenset 1.0 inclusief meetmethoden en referentiewaarden gebaseerd op twee eerdere studies voor het meten van indicatoren die kunnen worden gebruikt om te komen tot duurzaam bodembeheer. Vanuit de discussies over de achterliggende keuzes voor deze indicatoren en de doelstellingen in het Nationaal Bodemprogramma is de systematiek, die hier wordt beschreven, tot stand gekomen.

Bij het samenstellen van de systematiek is duidelijk geworden dat de belangrijkste reden van verschillen in uitspraken over bodemkwaliteit niet in eerste instantie veroorzaakt wordt door de uitgevoerde metingen maar door de doelen van de gebruikers. De doelen van de gebruiker bepalen welke indicatoren aan deze doelen gekoppeld zijn, en welke metingen dus uitgevoerd moeten worden en wanneer de kwaliteit van een bodem als goed of slecht beoordeeld wordt. Daarnaast is duidelijk geworden dat, hoewel niet geheel expliciet gemaakt in hoofdstuk 2 , een regelmatig terugkerende en volledige meting van de bodemkwaliteit van alle indicatoren uit de tabellen 1 en 2 met betrouwbare meetmethoden voor veel gebruikers te duur is. Veel goedkope meetmethoden zijn nog in ontwikkeling en daarbij ontbreekt vaak informatie over betrouwbaarheid en referentiewaarden. Uit eerste discussies over toepassing van de indicatorenset 1.0 in praktijk blijkt al dat we kunnen verwachten dat er keuzes gemaakt gaan worden in de indicatoren vanuit doelstelling, beschikbaar budget en betrouwbaarheid, ook bij de klassieke methodes.

Het consequent en regelmatig op één manier vaststellen van de bodemkwaliteit met deze wetenschappelijk onderbouwde basis methodiek lijkt dus problematisch, omdat kwaliteitsbeoordeling altijd is gekoppeld aan een specifiek doel. Een goed alternatief is dan een systematiek met advisering over de juiste indicatoren vanuit de doelstellingen en context van de gebruiker zodat de best beschikbare meetmethode voor de situatie gebruikt wordt en ook de context van de uitspraak over bodemkwaliteit wel gekend is. Een eerste aanzet voor deze systematiek wordt in dit hoofdstuk uitgewerkt.

\subsection{Vraagarticulatie}

Er ligt een wens voor een integrale systematiek voor het meten van bodemkwaliteit die zowel door private als publieke partijen gebruikt kan gaan worden om zo tot een gezamenlijke uitspraak te komen van de bodemkwaliteit in de landbouw. Dit is een lastige opgave:

- Ten eerste gaat het om duurzaam beheer waarbij het niet alleen gaat om de landbouwproductiefunctie van een bodem maar ook om de levering van andere ecosysteemdiensten gekoppeld aan klimaat, water en biodiversiteit. Er wordt gevraagd een integrale afweging te kunnen maken, rekening houdend met de diverse belangen van betrokken partijen en de eisen aan bodemkwaliteit gekoppeld aan de te leveren ecosysteem diensten van de bodem, ook voorbij landbouwkundig gebruik.
- Ten tweede is de bodem een complex systeem waarbij rekening gehouden moet worden met diverse fysische, chemische en biologische aspecten. Er zijn verschillende metingen nodig om een goed beeld te krijgen van deze aspecten van bodemkwaliteit.

- Ten derde variëren een aantal bodemkenmerken in ruimte, tijd en ten gevolge van veldomstandigheden, waardoor goede meetprotocollen nodig zijn om metingen goed te kunnen interpreteren en onderling te vergelijken.

- Ten vierde zijn los van het aantal metingen en de variabiliteit een aantal bodemkenmerken lastig om goed te meten en hebben we nog onvoldoende praktische kennis om maatregelen te adviseren op basis van meetresultaten die de bodemkwaliteit op het gewenste niveau brengen.

- Tot slot is het landgebruik divers (akkerbouw, grasland, tuinbouw met verschillende teelten) en wisselend in tijd (onder andere door vruchtwisseling), waarbij elke landgebruik zijn eigen eisen stelt aan de bodemkwaliteit en ook weer invloed heeft op de bodemkwaliteit. Zo verhoogt grasland het organisch stofgehalte en wat daalt met gebruik als bouwland.

Internationaal zijn in de afgelopen jaren meerdere systemen opgezet voor het vaststellen van bodemkwaliteit. Vaak zijn deze gericht op slechts één of enkele doelen en specifiek voor de context van grondsoort en landgebruik van een land of regio. Daarnaast bevatten veel van deze systemen een min of meer vaste lijst van indicatoren die bepaald moet worden die niet altijd aansluit bij de context of het doel waarvoor deze lijst gebruikt wordt.

Dit is niet gewenst in een situatie waarin diverse partijen met elk hun eigen specifieke doelen en mogelijkheden een enkele systematiek moeten gebruiken. Daarom is voor gebruik in Nederland een vertaling van de systemen naar Nederlandse context nodig waarbij rekening gehouden wordt met de wens om tot gezamenlijke uitspraken te komen. Logischer wijs zijn indicatoren en meetmethoden dan gezamenlijk vastgesteld. De keuze van indicatoren is altijd sterk afhankelijk van de doelen, context en randvoorwaarden. Daarnaast is de wens van de Nederlandse overheid dat private partijen de ruimte houden zelf op basis van de systematiek met eigen tools de markt op gaan. Dit geeft een voorkeur voor een flexibele maar afgebakende systematiek waarin gebruikers op basis van wetenschappelijke gronden gefundeerde keuzes voor indicatoren kunnen maken.

\subsection{De systematiek}

Voor het beoordelen van de bodemkwaliteit gekoppeld aan een gebruiksfunctie en/of een doel moet vastgesteld worden welke indicatoren en meetmethoden hierbij minimaal noodzakelijk zijn. De ontwikkelde systematiek is hierop gericht. Figuur 1 geeft de basis van de systematiek weer uitgewerkt in een beperkt voorbeeld. 
Gaande van links naar rechts wordt in de systematiek voor een bepaalde context en vooraf gedefinieerde doelen automatisch een lijst met geprioriteerde indicatoren voorgesteld waarbij ook rekening wordt gehouden met het belang van bodemfuncties voor bepaalde doelstellingen en voor bodemeigenschappen gekoppeld aan bepaalde bodemfuncties. Ook worden afwegingen over de eigenschappen van indicatoren meegewogen ten opzichte van de randvoorwaarden.

1. Als eerste maakt een gebruiker de keuze voor een specifieke combinatie van landgebruik en hoofdgrondsoort. Hierbij kunnen ook andere randvoorwaarden opgegeven worden als maximale kosten voor meten van indicatoren en de snelheid van bepaling, en nauwkeurigheid en betrouwbaarheid van de indicatoren.

2. Vervolgens kiest een gebruiker een doel van toepassing. Doelen zijn deels vooraf vastgesteld maar kunnen ook door gebruiker ingevuld worden. Voorbeelden van doelen zijn stabiele gewasopbrengst, koolstofopslag, reduceren nutriëntenverliezen of volledige duurzaam bodembeheer.

3. Bodemfuncties zijn gedefinieerd volgens overzicht en terminologie van Ten Berge en Postma (2010).

4. Bodemeigenschappen zijn afkomstig uit eerdere studies naar bodemindicatoren en worden gekoppeld aan de bodemfuncties met een prioritering (zeer belangrijk, belangrijk, onbelangrijk). Wanneer een bodemeigenschap geselecteerd wordt op basis van een bodemfunctie kan ook teruggekeken worden naar andere bodemfuncties waarmee deze eigenschap relatie heeft. Zo kunnen ook terugkoppelingen in beeld gebracht worden.

5. Indicatoren geven aan met welke variabele de verlangde informatie kan worden verkregen, inclusief eenheid en streefwaarden. Per indicator zijn ook streefwaardes of referentiewaardes beschikbaar die kunnen verschillen per doelstelling. De indicator kan direct overeenkomen met de vast te stellen bodemeigenschap maar de bodemeigenschap kan ook op andere wijzen indirect bepaald of benaderd worden.
6. Meetmethoden zijn opties om de indicator vast te stellen. De keuze uit mogelijke methoden is niet beperkt tot een kwantitatieve meting in het laboratorium, maar kan ook visuele - en veldwaarnemingen zijn of afkomstig zijn uit databestanden, kaarten of modellen. In de afweging van meetmethoden spelen eigenschappen als kosten, snelheid van bepaling, nauwkeurigheid en betrouwbaarheid een rol om tot een keuze te komen van de meetmethode. Deze eigenschappen worden gekoppeld aan het gekozen doel en de randvoorwaarden.

De systematiek geeft enerzijds een default resultaat maar is echter ook zo flexibel dat een gebruiker de default instellingen op elk niveau kan aanpassen voor de eigen situatie en doelstellingen. De geboden vrijheid in het systeem is groot omdat het onmogelijk is om alle situaties vooraf uit te werken. Het concreet benoemen van alle gemaakte keuzen verbetert de uiteindelijke selectie en maakt deze transparant. De systematiek kan worden ingevuld voor diverse soorten landgebruik, doelstellingen en randvoorwaarden. Dit zal waarschijnlijk leiden tot een grote verzameling tabellen en schema's. Een logische uitwerking zou met een modulaire aanpak en/of een app kunnen zijn.

Het verschil met bestaande systemen is dat, hoewel een aantal ingrediënten overeenkomt, bestaande systemen vaak weinig transparant zijn. In bestaande systemen worden vaak stappen tegelijkertijd gezet, zoals doel met bodemfunctie of bodemeigenschap met indicator. De combinatie van stappen maakt de afleiding van doel naar indicator en meetmethode onduidelijk. In onderstaand schema is nog geen waardering opgenomen van het belang van bodemfuncties voor een bepaalde doelstelling en bodemeigenschappen voor een bepaalde functie.

Figuur 1: Schema met functionele relaties als basis voor een systematiek voor de keuze van indicatoren voor bepaling van de bodemkwaliteit.

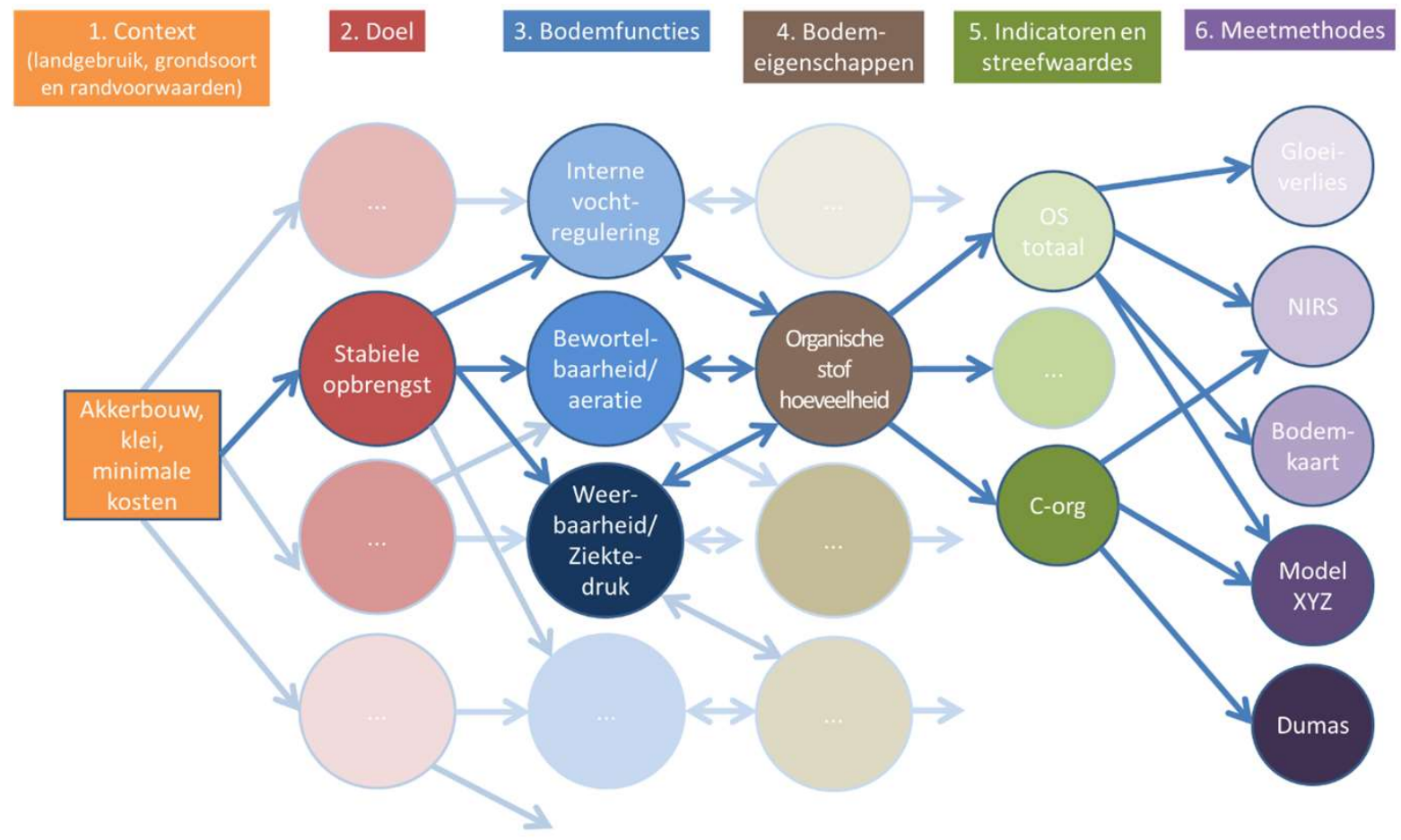




\subsection{Voorbeeld}

In deze paragraaf wordt het voorbeeld uit Figuur 1 verder beschreven volgens de uitleg uit de voorgaande paragraaf. In dit voorbeeld is de context gedefinieerd als akkerbouw, klei met een bepaling van de bodemkwaliteit tegen minimale kosten. Het gedefinieerde doel is stabiele opbrengst en bij dit doel is bekend dat (o.a.) de bodemfuncties interne vochtregulering, bewortelbaarheid/aeratie en weerbaarheid/ziektedruk van belang zijn. Meerdere bodemeigenschappen zijn gekoppeld aan deze drie bodemfuncties. Een bodemeigenschap die aan al deze drie bodemfuncties is gekoppeld, is de organische stofhoeveelheid. Deze bodemeigenschap kan direct gemeten worden (indicator OS-totaal), maar kan ook vastgesteld worden met de hoeveelheid organisch koolstof (indicator C-org) en mogelijk nog andere indicatoren. De indicatoren kunnen met verschillende meetmethoden worden vastgesteld, die elk hun eigen kenmerken hebben qua bijvoorbeeld kosten,

nauwkeurigheid en snelheid. De keuze van de methode hangt mede af van het doel. In dit voorbeeld, stabiele opbrengst, is geen nauwkeurige meting noodzakelijk. Gezien de randvoorwaarde minimale kosten is afleiding uit de bodemkaart het goedkoopste al krijg je ook een meetwaarde voor organische stof wanneer bijvoorbeeld een bodemvruchtbaarheidsanalyse wordt uitgevoerd. Dit is tegenwoordig vaak een spectroscopische meting met Near Infra Red (NIRS) die wat onnauwkeuriger maar goedkoper is dan de traditionele methode met gloeiverlies, maar voor dit doel goed genoeg.

Voor een ander doel, bijvoorbeeld koolstofopslag, kan ook de bodemeigenschap organische stof hoeveelheid van belang zijn. In dit geval is nauwkeurigheid van groter belang om veranderingen vast te stellen in de koolstofopslag en is een meting met een betrouwbare methode noodzakelijk. De indicator C-org met de meetmethode Dumas in dit geval beter dan OS-totaal vanwege de grotere nauwkeurigheid. Een alternatief is het berekenen van het organisch stofgehalte of koolstofgehalte met een model dat aanvoer en afbraak van organische stof over meerdere jaren berekend.

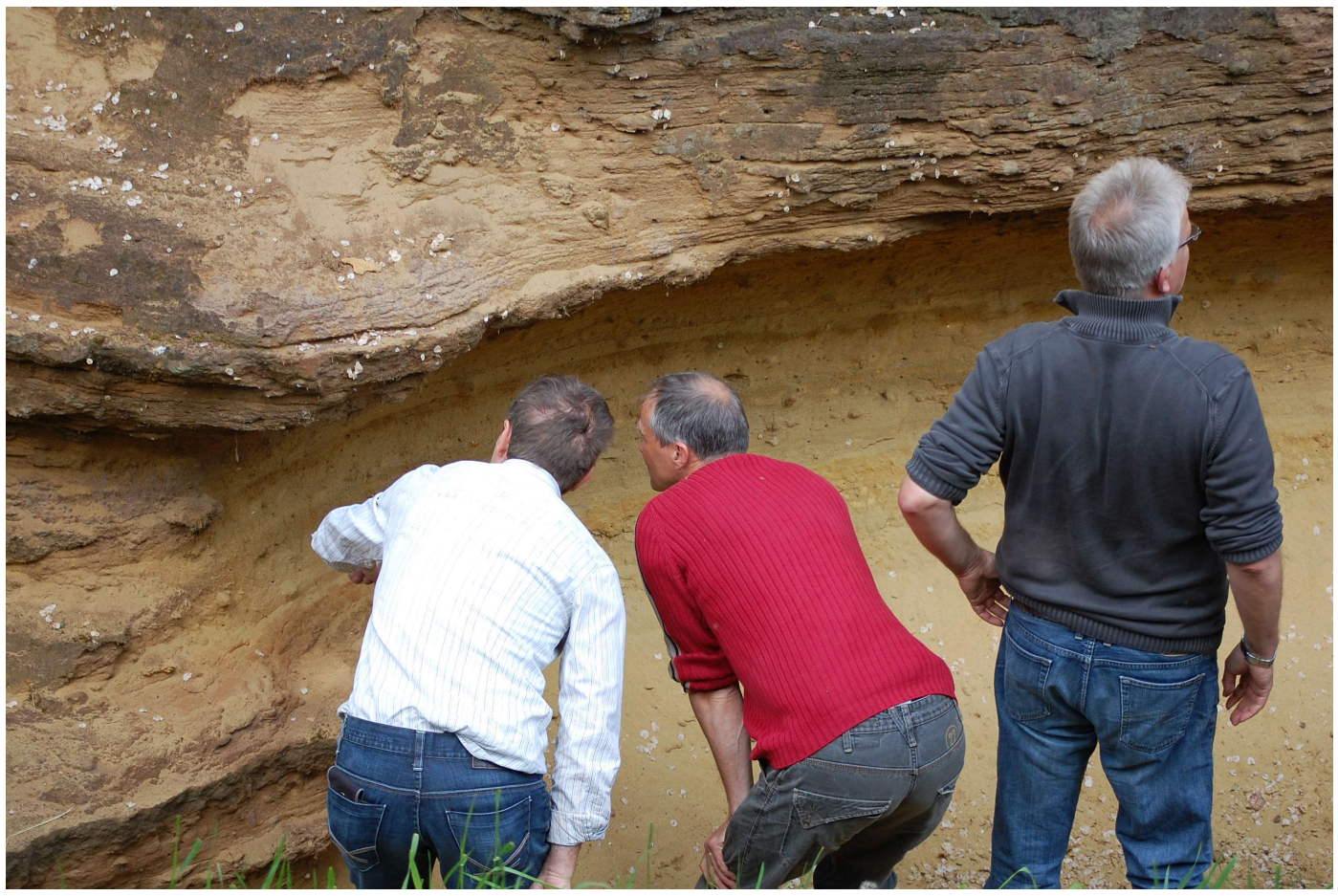




\section{Conclusies en aanbevelingen}

\subsection{Conclusies}

\section{Indicatorset bodemkwaliteit 1.0}

De gepresenteerde indicatorset, inclusief meetmethoden en referentiewaarden, is afgeleid uit de twee rapporten van den Elsen et al. (2019) en de Haan et al. (2019) en de systematiek zoals beschreven in hoofdstuk 3 . Deze wetenschappelijk onderbouwde indicatorset is een eerste aanzet voor akkerbouw en grasland op klei- en zandgrond, indicatorset bodemkwaliteit 1.0. Als zodanig betreft het een advies aan het Ministerie van LNV en potentiële gebruikers. In de uitwerking van indicatoren, meetmethoden en referentiewaarden zijn een aantal witte vlekken naar voren gekomen, met name op het gebied van snelle en/of goedkope meetmethoden en de beschikbaarheid van referentiewaarden en streefwaarden die ingevuld moeten worden voor een goed gebruik van de indicatorset.

\section{Systematiek voor meten van bodemkwaliteit}

$\mathrm{Bij}$ het samenstellen van de indicatorset bodemkwaliteit is duidelijk geworden dat de belangrijkste reden van verschillen in uitspraken over bodemkwaliteit niet veroorzaakt worden door de uitgevoerde metingen maar door de doelen van de gebruikers. Daarnaast is duidelijk geworden, hoewel niet expliciet gemaakt, dat een regelmatige en volledige meting van de bodemkwaliteit van alle indicatoren uit de tabellen 1 en 2 met betrouwbare meetmethoden voor veel gebruikers te duur is en dat veel goedkope meetmethoden nog in ontwikkeling zijn. Vanuit de wens naar eenduidigheid is daarom een systematiek met advisering over de juiste meetmethodes vanuit de doelstellingen van de gebruiker het beste alternatief. De systematiek biedt de mogelijkheid tot het selecteren van een verantwoorde subset die past bij de doelstellingen en context van de gebruiker.

\section{De systematiek biedt:}

een kader voor de afleiding van uiteenlopende instrumenten met een oplopend prijskaartje, van eenvoudige tools tot best mogelijke meetsystemen.

een advies aan de gebruiker voor een wetenschappelijk onderbouwde keuze van indicatoren en meetmethoden geprioriteerd op basis van de context (landgebruik en grondsoort), doel en randvoorwaarden.

de gebruiker flexibiliteit om de selectie van indicatoren aan te passen aan het specifieke doel en geeft de gebruiker inzicht in de afhankelijkheden van te meten bodemeigenschappen met andere bodemfuncties en doelstellingen.

De gepresenteerde systematiek doet recht aan de complexiteit van het begrip bodemkwaliteit en de diverse doelstellingen die gebruikers van dat begrip kunnen hebben. De systematiek zal de wens van eenduidige uitspraken over bodemkwaliteit niet geheel kunnen vervullen. Wel zal de systematiek duidelijkheid geven wat betreft de doelstellingen en achtergronden waarop een beoordeling van de bodemkwaliteit tot stand is gekomen. Gebruikers kunnen in het gebruik van dezelfde systematiek toewerken naar afstemming van indicatoren en meetmethoden zodat zoveel mogelijk dezelfde metingen gedaan worden.
In de toekomst kunnen ook handelingen en maatregelen gekoppeld worden aan de systematiek. In sommige gevallen kan een maatregel zelf indicatief zijn voor bodemkwaliteit, bijvoorbeeld een maatregel als 'niet scheuren van grasland'. Met de koppeling aan maatregelen wordt het mogelijk om gerichte adviezen te geven wanneer uit de metingen van de indicatoren blijkt dat de bodemeigenschappen nog onvoldoende zijn om de doelstellingen te realiseren.

\section{Draagvlak}

$\mathrm{Er}$ is nog niet gewerkt aan brede draagvlakontwikkeling bij private en publieke partijen rond deze indicatorset en systematiek.

\subsection{Aanbevelingen}

De volgende aanbevelingen worden gedaan:

\section{BLN versie 1.0}

1. Zorg voor een volledige uitwerking van referentiewaarden en streefwaarden voor alle grondsoorten en

landgebruiksvormen in de landbouwsector van Nederland. Sluit wat landgebruik classificatie betreft aan bij de indeling die in het project CC-NL binnen de klimaatenvelop Slim Landgebruik. Pas indien noodzakelijk de indicatorset en meetmethoden aan voor andere grondsoorten en landgebruik. Kijk hierbij ook naar kosten van de indicatorset en draagvlak en uitvoerbaarheid bij laboratoria om het volgens het advies uit te voeren. Maak een uitbreiding c.q. koppeling met maatregelen mogelijk.

2. Zorg voor nadere uitwerking van richtlijnen voor de robuustheid van het indicatorsysteem als geheel en voor validatie van met name de 'snel \& goedkoop' meettechnieken.

3. Toetsing van de indicatorset en systematiek met private partijen (marktpartijen, o.a. adviseurs, toolontwikkelaars).

\section{Systematiek voor meten van bodemkwaliteit}

4. Zorg voor volledige uitwerking van de gepresenteerde systematiek wat betreft de beschrijving van bodemfuncties, bodemeigenschappen, indicatoren (met eenheden) en streef- en referentiewaarden en protocollen van meetmethoden.

5. Bij de meetmethoden is tevens aandacht gewenst voor de nauwkeurigheid, betrouwbaarheid en kosten van meetmethoden en waar witte vlekken zitten in de beschikbaarheid van snelle en goedkope meetmethoden.

6. Om het gebruik van de indicatorset en de systematiek te stimuleren is het zinvol om op basis van de volledige uitwerking een applicatie te (laten) ontwikkelen.

\section{Draagvlak}

7. Ontwikkel draagvlak voor de BLN en systematiek bij zowel private en publieke partijen; hiervoor kan dit rapport als vertrekpunt dienen voor een verkenning van mogelijke toepassingen in de praktijk. 


\section{Literatuur}

- Aaltjesschema, Wageningen University \& Research Open Teelten: www.aaltjesschema.nl

- Bemestingsadvies Commissie Bemesting Grasland en Voedergewassen: http://www.bemestingsadvies.nl

- Berge H ten \& J Postma (Eds.), 2010. Duurzaam bodembeheer in de Nederlandse landbouw. Visie en bouwstenen voor een kennisagenda. Plant Research International, onderdeel van Wageningen UR. http://edepot.wur.nl/167923.

- Bünemann, Else K., Giulia Bongiorno, Zhanguo Bai, Rachel E. Creamer, Gerlinde De Deyn, Ron de Goede, Luuk Fleskens, Violette Geissen, Thom W. Kuyper, Paul Mäder, Mirjam Pulleman, Wijnand Sukkel, Jan Willem van Groenigen, Lijbert Brussaard. 2018, Soil quality - A critical review, Soil Biology and Biochemistry, Volume 120, Pages 105-125, ISSN 0038-0717, https://doi.org/10.1016/j.soilbio.2018.01.030.

- Eekeren, N. Van \& J. Bokhorst, 2009. Beoordeling bodemkwaliteit zandgrond. Een inventarisatie van bodemindicatoren voor de veehouderij. Zorg voor Zand Rapport nr. 7. Louis Bolk Instituut. Driebergen. 61 pp. http://www.louisbolk.org/downloads/2149.pdf

- Elsen, H.G.M. van den, M. Knotters, M. Heinen, P.F.A.M. Römkens, J. Bloem, \& G.W. Korthals, 2019. Noodzakelijke indicatoren voor de beoordeling van de gezondheid van Nederlandse landbouwbodems; De meest relevante fysische, chemische en biologische indicatoren voor het meten van de bodemgezondheid. Rapport 2944, Wageningen

Environmental Research. http://edepot.wur.nl/475874.

- Eijkelkamp Soil \& Water: Wet Sieving Apparatus - Manual M-0813E, Eijkelkamp, Giesbeek, NL

(https://www.eijkelkamp.com/download.php?file $=$ M0813e Wet_sieving_apparatus_d495.pdf)

- Haan, J.J. de, S. Rombouts. L. Molendijk, W. Sukkel, H. Hoek \& T. Thoden. 2019. Meten is Weten Weten Wageningen University \& Research - in press.

- Hanegraaf M.C. \& F. van Alebeek (2014) Meetset Biologische Bodemkwaliteit. Masterplan Mineralen management. PPO/NMI. http://edepot.wur.nl/292711.

- Hanegraaf MC, HC de Boer, N van Eekeren \& DW Bussink, 2009. Schatting van $\mathrm{C}$ - en $\mathrm{N}$-mineralisatie met indicatoren voor labiele organische stof en stikstof. NMI-rapport 1230, NMI, Wageningen.

- Hack-ten Broeke, M.J.D., S.L.G.E. Burgers, A. Smit, H.F.M. ten Berge, J.J. de Gruijter, I.E. Hoving, M. Knotters, S. Radersma en G.L. Velthof, 2004. Ontwikkeling van een indicator om te Sturen Op Nitraat; Gegevens en regressieanalyse op basis van drie meetseizoenen (20002001, 2001-2002 en 2002-2003). Wageningen, Alterra, Alterra-rapport 1053. Sturen op Nitraat 12. $117 \mathrm{blz} .14$ fig.; 49 tab.; 26 ref. http://edepot.wur.nl/26775

- Handboek Bodem en Bemesting, Commissie Bemesting Akkerbouw en Vollegrondsgroenten: www.handboekbodemenbemesting.nl

- Heinen et al., 2019 (in prep.) Waterretentie- en doorlatendheidskarakteristieken van boven- en ondergronden in Nederland: de Staringreeks. Update 2018.

- Koopmans, C.J., L. Brands. 2002. Ondersteuning van duurzaam bodembeheer - Testkit bodemkwaliteit. Louis Bolk Instituut, Driebergen. $96 \mathrm{p}$.
- Ministerie van Landbouw, Natuur \& Voedselkwaliteit. 2019. Kamerbrief over nationaal programma landbouwbodems. 25-042019.

https://www.rijksoverheid.nl/binaries/rijksoverheid/documenten kamerstukken/2019/04/25/kamerbrief-over-het-nationaalprogramma-landbouwbodems/kamerbrief-over-het-nationaalprogramma-landbouwbodems.pdf.

- Moebius-Clune, B.N., D.J. Moebius-Clune, B.K. Gugino, O.J. Idowu, R.R. Schindelbeck, A.J. Ristow, H.M. van Es, J.E. Thies, H.A. Shayler, M.B. McBride, K.S.M Kurtz, D.W. Wolfe, and G.S. Abawi, 2016. Comprehensive Assessment of Soil Health - The Cornell Framework, Edition 3.2, Cornell University, Geneva, NY.

- NEN 5753 en/of ISO 11277 - Bepaling van het lutumgehalte en de korrelgrootteverdeling in grond en waterbodem met behulp van zeef en pipet.

- NEN-EN-ISO 11272:2017 - Bepaling van de droge bulkdichtheid

- Nimmo, J.R. \& K.S. Perkins. 2002. Aggregate Stability and Size Distribution. In: J.H. Dane \& G.C. Topp (eds.), Methods of Soil Analysis. Part 4. Physical Methods, pp. 317-328. Soil Science Society of America, Inc., Madison, Wisconsin, USA.

- Rutgers, M.; Mulder, C.; Schouten, A.J.; Bloem, J.; Bogte, J.J.; Breure, A.M.; Brussaard, L.; Goede, R.G.M. de. 2007. Typeringen van bodemecosystemen in Nederland. Met tien referenties voor biologische bodemkwaliteit. RIVM rapport 607604008/2007. http://edepot.wur.nl/40979.

- Van Erp, P.J.,2002. The potentials of multi-nutrient soil extraction with $0.01 \mathrm{M} \mathrm{CaCl} 2$ in nutrient management. Dissertatie Wageningen Universiteit.

- Van Rotterdam-Los, A.M.D. 2010 The potential of soils to supply phosphorus and potassium : processes and predictions. Dissertatie Wageningen Universiteit.

- Wösten, J.H.M., G.J. Veerman, W.J.M. de Groot \& J. Stolte. 2001. Waterretentie- en doorlatendheidskarakteristieken van boven- en ondergronden in Nederland: de Staringreeks Vernieuwde uitgave 2001. Alterra rapport 153, Alterra, Wageningen. 


\section{Bijlage 1 Achtergronden bij Minimale Dataset en de ontwikkeling van de Soil Health Index voor Nederland}

\section{Minimale Data Set (MDS)}

De lijst van indicatoren in de Minimale Dataset (MDS) kwam voort uit de behoefte om, gegeven het stringente mineralenbeleid, de bodemkwaliteit beter in kaart te brengen. Hiertoe is een screening gemaakt van indicatoren uit de literatuur, onder meer op hun geschiktheid voor gebruik in de Nederlandse landbouw. De uiteindelijke keuze van indicatoren in de MDS zijn vastgesteld in een stakeholder-proces. De totale lijst omvat 45 indicatoren: 23 prioriteit ' 1 ', 15 type ' 2 ', 4 type ' 3 ' en 3 type ' 4 '. De type ' 1 ' indicatoren bevatten 6 fysische, 13 chemische en 4 biologische indicatoren die routinematig of experimenteel bepaald worden (de Haan et al., 2019).

\section{Ontwikkeling van de Soil Health Index (SHI) voor Nederland}

Voor de ontwikkeling van de Soil Health Index (SHI) voor Nederland zijn indicatoren geselecteerd analoog aan eerder ontwikkelde indicator systemen c.q. literatuuroverzichten zonder daarbij te streven naar gelijkvormigheid en gerelateerd aan / gekozen op basis van de Cornell Comprehensive Assessment of Soil Health en Bünemann et al. (2018); een metastudie van 64 bodemkwaliteitssystemen. Bij de selectie van indicatoren is rekening gehouden met de hedendaagse (2019) Nederlandse bodembedreigingen op fysisch, chemisch en biologisch vlak (van den Elsen et al., 2019 - paragrafen 2.2, 3.2 en 4.2).

De totale lijst omvat 21 indicatoren, waarvan 12 absoluut noodzakelijke indicatoren (klasse ' $A$ ') en 9 'add-on' indicatoren die ingezet worden als de bodemomstandigheden daar aanleiding toe geven (van den Elsen et al., 2019 paragraaf 5.2).

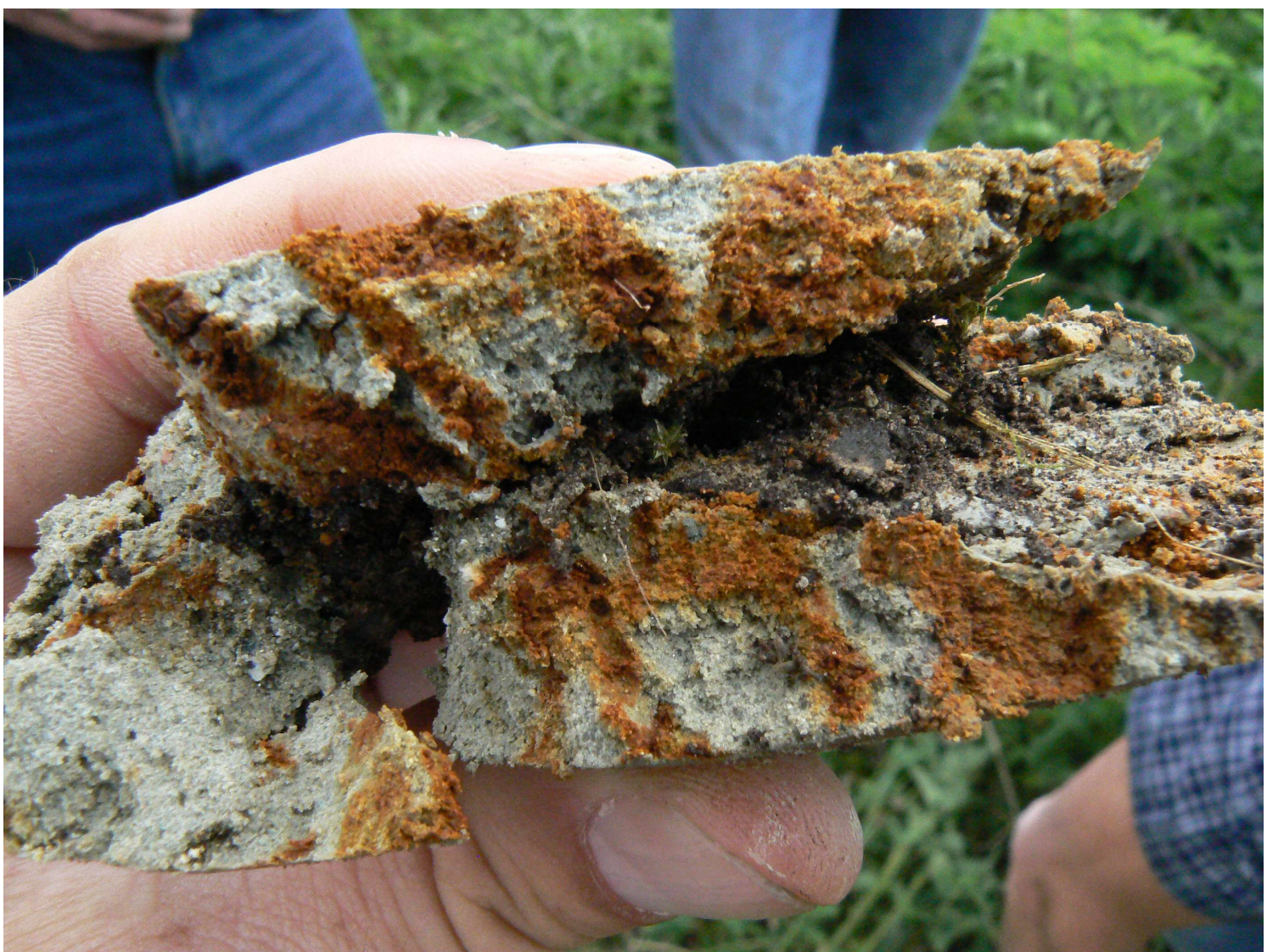




\section{Bijlage 2 \\ Robuustheid van het indicatorsysteem}

De meettechnische robuustheid (het onafhankelijk zijn van omgevingsfactoren) van het indicatorsysteem hangt af van de nauwkeurigheid van de metingen en een aantal andere zaken. Niet alle omgevingsfactoren hebben invloed op alle indicatoren (afhankelijkheid wordt in tabel 3 weergegeven):

1. Meetnauwkeurigheid en precisie van gekozen

meettechnieken

- Afhankelijkheid van metacondities (temperatuur, bodemvocht, weer (weersgeschiedenis))

- Afhankelijkheid van veldvariabiliteit (goede

steekproefopzet noodzakelijk)

- Afhankelijkheid van het historisch management

- Afhankelijkheid van het verbouwde gewas

Om iets van de robuustheid van het totale indicatorsysteem te kunnen zeggen, moet elke component hierboven afzonderlijk worden geanalyseerd. Op dit moment kan de nauwkeurigheid en precisie van de preferente meetmethoden goed worden beschreven (een indicatie hiervan wordt in Tabel 4 kolom nauwkeurigheid gegeven). Mogelijk is voor een meetmethode een alternatieve (NIRS) variant voorhanden die voldoende nauwkeurig is en ook goedkoper. De meest geschikte meetmethode voor elke indicator moet worden bepaalde aan de hand van een uitvoeriger analyse van methoden, welke deels ook nog aan de hand van praktijkproeven moeten worden getest. In een dergelijke analyse kan ook worden aangegeven voor welke klassieke meetmethoden snelle alternatieven zouden moeten worden en kunnen ontwikkeld.

De veldvariabiliteit kan op effectieve wijze worden omzeild door een geschikte bemonsteringsstrategie te ontwerpen.

De invloed van andere factoren op het indicatorsysteem (metacondities, historisch management, gewas) is op dit moment onvoldoende bekend om hier iets over te zeggen. In van den Elsen et al., 2019 - hoofdstuk 5, wordt de invloed van temperatuur, bodemvochtgehalte en weer (weersgeschiedenis) verder beschreven. Dit rapport geeft een goede, inleidende beschrijving op deze zaken, maar moet verder worden uitgewerkt. Of voor al de genoemde invloeden kan worden gecompenseerd is maar zeer de vraag. Wellicht is het praktischer richtlijnen op te stellen waarbinnen metingen aan indicatoren zouden moeten plaatsvinden voor de genoemde factoren (bijvoorbeeld: veldmetingen moeten plaatsvinden binnen bepaalde

Tabel 3: Indicatie van de beoordeling van de afhankelijkheid van indicatoren en betrouwbaarheid, nauwkeurigheid en kosten van de preferente meetmethoden (bron: van den Elsen et al., 2019). Indicatorset in deze tabel komt niet helemaal overeen met de indicatorset in de tabellen 1 en 2. Deze tabel moet gezien worden als illustratie bij de tekst in deze bijlage.

\begin{tabular}{|c|c|c|c|c|c|c|c|c|}
\hline Gebied & & & Indicator & & hankelijk-heid $^{1}$ & Methode & $\begin{array}{c}\text { Betrouwbaarheid, } \\
\text { nauwkeurigheid }\end{array}$ & Kosten \\
\hline \multirow{5}{*}{$\begin{array}{l}\frac{5}{y} \\
\frac{n}{n} \\
\frac{1}{4}\end{array}$} & 1 & 1 & Watervasthoudend vermogen & A & S, B & Zandbak/drukpan & $\bullet \bullet \bullet$ & $\bullet \bullet \bullet$ \\
\hline & 2 & 2 & Aggregaatstabiliteit & A & $\theta, \mathrm{T}, \mathrm{S}, \mathrm{B}$ & Natte zeef methode & $\bullet \bullet \bullet$ & $\bullet \bullet \bullet$ \\
\hline & 3 & 3 & Textuur & A & $\mathrm{B}$ & Pipetmethode & $\bullet \bullet \bullet$ & $\bullet$ \\
\hline & 4 & 4 & Indringingsweerstand & A & $\theta, \mathrm{B}$ & Penetrometer & $\bullet \bullet$ & $\bullet$ \\
\hline & 5 & 5 & Droge bulkdichtheid & + & $\theta, \mathrm{B}$ & Massa na drogen $105 \mathrm{C}$ & $\bullet \bullet \bullet$ & $\bullet \bullet$ \\
\hline \multirow{8}{*}{ 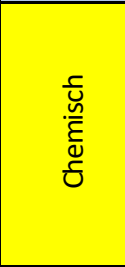 } & 6 & 1 & OS-gehalte & A & $\mathrm{B}, \mathrm{G}$ & Gloeiverlies & $\bullet$ & $\bullet \bullet$ \\
\hline & 7 & 2 & C-gehalte & A & $\mathrm{B}, \mathrm{G}$ & Dumas & $\bullet \bullet \bullet$ & $\bullet \bullet$ \\
\hline & 8 & 3 & $\mathrm{pH}$ & A & $\mathrm{B}, \mathrm{G}$ & $\mathrm{pH}(\mathrm{KCl}), \mathrm{pH}(\mathrm{CaCl} 2)$ & $\bullet \bullet$ & $\bullet \bullet$ \\
\hline & 9 & 4 & Ntotaal & A & $\theta, \mathrm{B}$ & Kjeldahl + extractie in $\mathrm{CaCl} 2$ & $\bullet \bullet \bullet$ & $\bullet \bullet$ \\
\hline & 10 & 5 & Nmin & A & $\theta, \mathrm{B}, \mathrm{G}$ & Extractie in $\mathrm{CaCl} 2$ & $\bullet \bullet \bullet$ & $\bullet \bullet$ \\
\hline & 11 & 6 & P voorraad + beschikbaar & A & $\theta, \mathrm{B}, \mathrm{G}$ & extractie in ammoniumlactaat- azijnzuu & $\bullet \bullet \bullet$ & $\bullet \bullet$ \\
\hline & 12 & 7 & K voorraad + beschikbaar & + & $\mathrm{B}, \mathrm{G}$ & ? + extractie in $\mathrm{HCl}$ & & $\bullet$ \\
\hline & 13 & 8 & OS (stabiele fractie) & + & $\mathrm{B}, \mathrm{G}$ & oxidatie in permanganaat (POXC) & n.b. & n.b. \\
\hline \multirow{7}{*}{ 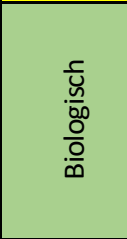 } & 14 & 1 & Potentieel Mineraliseerbare N (PMN) & A & $\theta, T, S, B, G$ & anaerobe incubatie & $\bullet \bullet \bullet$ & $\bullet \bullet \bullet$ \\
\hline & 15 & 2 & Aaltjes - diversiteit en aantallen & A & $\theta, T, S, B, G$ & microscopie & $\bullet \bullet \bullet$ & $\bullet \bullet \bullet$ \\
\hline & 16 & 3 & Schimmels - soorten en aantallen & A & $\theta, T, S, B, G$ & PCR + microscopie & $\bullet \bullet \bullet$ & $\bullet \bullet \bullet$ \\
\hline & 17 & 4 & Heet water extraheerbare Carbon - HWC ${ }^{1}$ & A & $\theta, T, S, B, G$ & extractie in heet water & $\bullet \bullet \bullet$ & $\bullet \bullet \bullet$ \\
\hline & 18 & 5 & Bacteriële biomassa & + & $\theta, \mathrm{T}, \mathrm{S}, \mathrm{B}, \mathrm{G}$ & PLFA & $\bullet \bullet$ & $\bullet \bullet \bullet$ \\
\hline & 19 & 6 & Schimmelbiomassa & + & $\theta, \mathrm{T}, \mathrm{S}, \mathrm{B}, \mathrm{G}$ & PLFA & $\bullet \bullet \bullet$ & $\bullet \bullet \bullet$ \\
\hline & 20 & 7 & Regenwormen (aantallen en diversiteit) & + & $\theta, \mathrm{T}, \mathrm{S}, \mathrm{B}, \mathrm{G}$ & visueel & $\bullet \bullet \bullet$ & $\bullet \bullet \bullet$ \\
\hline Algemeen & 21 & 1 & Visuele beoordeling (Fys/Chem/Biol) & + & $\theta, S, B, G$ & visueel & $\bullet \bullet$ & $\bullet \bullet \bullet$ \\
\hline
\end{tabular}

Aanvullende selectie o.b.v.:

-referentiewaarden beschikbaar ja/nee

- betrouwbaarheid, nauwkeurigheid

kosten 
temperatuurgrenzen en binnen bepaalde waarden van bodemvochtgehalte) om te voorkomen dat externe factoren te veel invloed uitoefenen. De invloed van externe factoren zouden in toekomstige veldproeven en/of pilots moeten worden onderzocht om de robuustheid van het voorgestelde indicatorsysteem te kunnen waarborgen.

Uit kostenoogpunt is er een voorkeur voor indicatoren die met andere snelle en goedkopere methoden kunnen worden bepaald (zie Tabel 4), daar waar de vereiste nauwkeurigheid dit toelaat. Daar waar snelle methoden niet beschikbaar zijn voor een indicator moet worden teruggevallen op klassieke bepalingsmethoden.

Met betrekking tot de robuustheid van het totale indicatorsysteem en de verschillende aspecten kunnen we het volgende concluderen:

\section{Meetnauwkeurigheid en precisie van gekozen} meettechnieken

Voor de klassieke meetmethoden is de nauwkeurigheid bekend. Voor de snelle en goedkope technieken moet de nauwkeurigheid van de meeste metingen worden onderzocht en moet worden bekeken of de nauwkeurigheid hiervan voldoende is voor het doen van uitspraken over de bodemkwaliteit.

advies: inventariseren en verder uitwerken

2. Afhankelijkheid van metacondities (temperatuur, bodemvocht, weer (weersgeschiedenis))

Een aantal metingen worden aan monsters onder geconditioneerde omstandigheden uitgevoerd, deze hebben geen last van variërende veldomstandigheden temperatuur en bodemvocht. Van een aantal andere meetmethoden die onder niet-geconditioneerde veldomstandigheden worden uitgevoerd moet de afhankelijkheid van metacondities worden uitgezocht (literatuur en indien nodig veldproeven) om de randvoorwaarden voor veldmetingen te bepalen.. advies: inventariseren en verder uitwerken.

Randvoorwaarden voor veldmetingen opstellen.

1. Afhankelijkheid van veldvariabiliteit (goede steekproefopzet noodzakelijk)

Aan de hand van de lijst met bodemsoort / landgebruik combinaties moet worden bekeken welke afwijkende combinaties een eigen steekproefopzet nodig zal hebben, anders kan met een standaard steekproefopzet worden gewerkt om voor de veldvariabiliteit te compenseren. advies: afwijkende bodemsoort / landgebruik combinaties bepalen en geschikte steekproefopzet ontwerpen

2. Afhankelijkheid van het historisch management Ten gevolge van het management van op een perceel tot nu toe zal de bodemkwaliteit ervan zijn beïnvloed. Het wordt echter verwacht dat deze bodemkwaliteit gewoon kan worden gemeten met de indicatorset en dat de betrouwbaarheid van de meting niet wordt beïnvloed door de management geschiedenis van een perceel. advies: geen speciale maatregelen

3. Afhankelijkheid van het verbouwde gewas Ten gevolge van de gewaskeuze op een perceel tot nu toe zal de bodemkwaliteit ervan zijn beïnvloed. Het wordt echter verwacht dat deze bodemkwaliteit gewoon kan worden gemeten met de indicatorset en dat de betrouwbaarheid van de meting niet wordt beïnvloed door de gewaskeuze in het verleden. advies: geen speciale maatregelen

Tabel 4: Indicatie van de beoordeling van de afhankelijkheid van indicatoren en betrouwbaarheid, nauwkeurigheid en kosten van goedkope en snelle meetmethoden. Bron: van den Elsen et al, 2019. Indicatorset in deze tabel komt niet helemaal overeen met de indicatorset in de tabellen 1 en 2. Deze tabel moet gezien worden als illustratie bij de tekst in deze bijlage.

\begin{tabular}{|c|c|c|c|c|c|c|c|c|c|}
\hline Gebied & & & Indicator & & $\begin{array}{c}\text { Afhankelijk- } \\
\text { heid }^{1}\end{array}$ & Methode & $\begin{array}{l}\text { Betrouwbaarheid, } \\
\text { Nauwkeurigheid }\end{array}$ & Kosten & $\begin{array}{l}\text { Beschikbaarh. } \\
\text { Ref.waarden }\end{array}$ \\
\hline \multirow{5}{*}{ 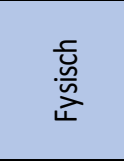 } & 1 & 1 & Watervasthoudend vermogen & A & S, B & o.b.v. textuur + OS & $\bullet \bullet$ & $\bullet \bullet \bullet$ & ja \\
\hline & 2 & 2 & Aggregaatstabiliteit & A & $\theta, \mathrm{T}, \mathrm{S}, \mathrm{B}$ & experimenteel NIRS & n.b. & n.b. & nee \\
\hline & 3 & 3 & Textuur & A & $\mathrm{B}$ & NIRS & n.b. & $\bullet \bullet \bullet$ & ja \\
\hline & 4 & 4 & Indringingsweerstand & A & $\theta, \mathrm{B}$ & & & & \\
\hline & 5 & 5 & Droge bulkdichtheid & + & $\theta, \mathrm{B}$ & experimenteel NIRS & n.b. & n.b. & nee \\
\hline \multirow{8}{*}{$\begin{array}{l}\text { 들 } \\
\frac{\mathscr{E}}{\Phi} \\
\frac{\mathcal{U}}{U}\end{array}$} & 6 & 1 & OS-gehalte & A & $B, G$ & NIRS & n.b. & $\bullet$ & ja \\
\hline & 7 & 2 & C-gehalte & A & $\mathrm{B}, \mathrm{G}$ & NIRS & n.b. & $\bullet$ & ja \\
\hline & 8 & 3 & $\mathrm{pH}$ & A & $B, G$ & NIRS & n.b. & - & ja \\
\hline & 9 & 4 & Ntotaal & A & $\theta, \mathrm{B}$ & NIRS & n.b. & $\bullet$ & ja \\
\hline & 10 & 5 & Nmin & A & $\theta, \mathrm{B}, \mathrm{G}$ & NIRS & n.b. & $\bullet$ & ja \\
\hline & 11 & 6 & P voorraad + beschikbaar & A & $\theta, \mathrm{B}, \mathrm{G}$ & $\mathrm{PAL}+\mathrm{PAE}$ & n.b. & $\bullet$ & ja \\
\hline & 12 & 7 & K voorraad + beschikbaar & + & $B, G$ & $\mathrm{NIRS}+\mathrm{PAE}$ & n.b. & $\bullet$ & ja \\
\hline & 13 & 8 & OS (stabiele fractie) & + & $B, G$ & n.b. & n.b. & $\bullet$ & n.b. \\
\hline \multirow{7}{*}{$\begin{array}{l}\text { 듬 } \\
\frac{\mathscr{n}}{00} \\
\frac{0}{0} \\
\frac{0}{0}\end{array}$} & 14 & 1 & Potentieel Mineraliseerbare N (PMN) & A & $\theta, \mathrm{T}, \mathrm{S}, \mathrm{B}, \mathrm{G}$ & NIRS & n.b. & $\bullet$ & ja \\
\hline & 15 & 2 & Aaltjes - diversiteit en aantallen & A & $\theta, T, S, B, G$ & PCR & n.b. & n.b. & n.b. \\
\hline & 16 & 3 & Soorten en aantallen pathogene schimmels & A & $\theta, T, S, B, G$ & n.b. & n.b. & n.b. & n.b. \\
\hline & 17 & 4 & Heet water extraheerbare Carbon - HWC ${ }^{1}$ & A & $\theta, T, S, B, G$ & R\&D NIRS & n.b. & n.b. & nee \\
\hline & 18 & 5 & Bacteriële biomassa & + & $\theta, T, S, B, G$ & NIRS & n.b. & $\bullet$ & ja \\
\hline & 19 & 6 & Schimmelbiomassa & + & $\theta, T, S, B, G$ & NIRS & n.b. & $\bullet$ & ja \\
\hline & 20 & 7 & Regenwormen (aantallen en diversiteit) & + & $\theta, T, S, B, G$ & & & & \\
\hline Algemeen & 21 & 1 & Visuele beoordeling (Fys/Chem/Biol) & + & $\theta, S, B, G$ & & & & \\
\hline
\end{tabular}

1) afhankelijkheid: $T=$ temperatuur, $\theta=$ watergehalte, $S=$ seizoen, weer, $B=$ Bodemtype, Gewas

Aanvullende selectie o.b.v.:

referentiewaarden beschikbaarja/nee

betrouwbaarheid, nauwkeurigheid

kosten

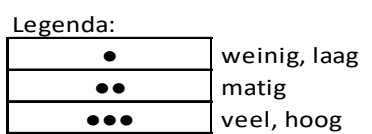




\section{Bijlage 3}

\section{Interpretatie van meetwaarden, classificatie, beoordeling en normalisatie}

\section{Inleiding}

$\mathrm{Na}$ het vaststellen van geschikte indicatoren en daarbij behorende meetmethoden komen vervolgens de interpretatie en eventueel ook classificatie aan de beurt. Dit is belangrijk omdat in deze stap wordt bepaald of een gemeten waarde in de buurt van een referentiewaarde komt, dus eigenlijk of de gemeten waarde van een indicator 'goed' is dat deze ervan afwijkt. De mate waarin een indicatorwaarde afwijkt van de referentiewaarde zegt iets over hoe 'goed' de meetwaarde is en of zou moeten worden geprobeerd de meetwaarde te verbeteren. Als we het hebben over het beoordelen van hoe goed of slecht een meetwaarde is hebben we het over classificatie. Een duidelijk, begrijpelijk classificatiesysteem is belangrijk om interpretatie van meetwaarden voor iedereen begrijpelijk te maken.

\section{Classificatie}

Zoals al in de inleiding van dit hoofdstuk werd genoemd, is een goed classificatiesysteem bedoeld voor het eenduidig en begrijpelijk maken van de resultaten van indicatormetingen. Dit is belangrijk omdat maar weinig mensen de directe uitkomsten van indicatormetingen, in SI eenheden, kunnen duiden en interpreteren. Een classificatiesysteem zorgt voor de beoordeling van indicatormetingen in klassen die voor iedereen te begrijpen is. Voor elke bodemtype / landgebruik combinatie dient een specifieke variant van het classificatiesysteem te worden gebruikt Er kunnen diverse typen classificatiesystemen worden gebruikt:

\section{Referentiewaarde}

Dit is eigenlijk geen classificatiesysteem. Voor een bepaalde indicator in een bodemtype / landgebruikscombinatie wordt per indicator een referentiewaarde gegeven. Indien een indicatormeting afwijkt van (vaak: lager is dan) de referentiewaarde weet een landgebruiker dat hij door management zou moeten bijsturen om de referentiewaarde te bereiken. In dit systeem weet de landgebruiker echter niet hoe goed of slecht de afwijking van de referentiewaarde is.

\section{Discrete classificatie}

Een discreet classificatiesysteem maakt gebruik van referentiewaarden als uitgangspunt en geeft in klassengrenzen aan voor de mate van afwijking van een indicatormeetwaarde (zie Figuur 1, links). Bijvoorbeeld de referentiewaarde is 10 , zodra de meetwaarde met 2 zakt wordt de beoordeling slechter (b.v. een meetwaarde van: 6, 5, 4, 3, 2 geeft een beoordeling van: uitmuntend, goed, matig, slecht, zeer slecht). Nadeel van een dergelijk systeem is dat kleine veranderingen (lees: verbeteringen) in een indicatormeting slechts dan tot veranderingen in de classificatie leiden als de classificatiegrens wordt overschreden (b.v. van 3.9 -> 4.1). Dit betekent dat een landgebruiker minder vaak resultaat ziet van zijn inspanningen om zijn bodemkwaliteit te verbeteren.

\section{Continue classificatie}

Een continue classificatiesysteem maakt gebruik van referentiewaarden als uitgangspunt maar beschrijft afwijkende waarden als een continue grafiek (zie Figuur 1, rechts) zodat een meetwaarde continue wordt omgezet naar een score tussen bijvoorbeeld 0 en 100. Dit kan ook nog worden gekoppeld aan een additionele, visuele beoordeling in kleuren zoals in de figuur is gedaan. Het voordeel van een dergelijk systeem is dat kleine veranderingen (lees: verbeteringen) direct zichtbaar worden in de beoordeling (b.v. een indicator meetwaardeverandering van 4 naar 4.2 kan dan bijvoorbeeld kunnen resulteren in een scoreverbetering van 50 naar 55 en vallen in klasse 'oranje'. Dit betekent dat een landgebruiker direct resultaat ziet van zijn inspanningen om zijn bodemkwaliteit te verbeteren. Nadeel van deze methode is dat de nauwkeurigheid van de meetmethode ten minste zo nauwkeurig moet zijn dat relatief kleine scoreverschillen gedetecteerd kunnen worden.

Figuur 2: Voorbeelden van een discreet (links) en een continue (rechts) classificatiesysteem.

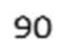

90

70

50

30

10

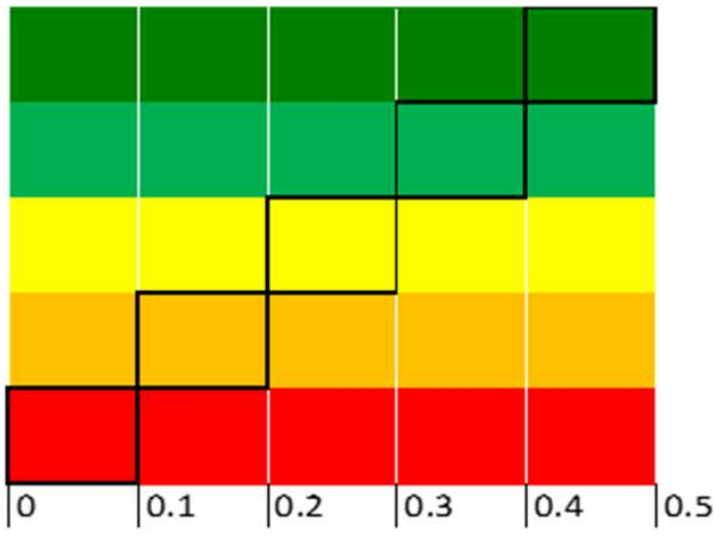

Meetwaarde

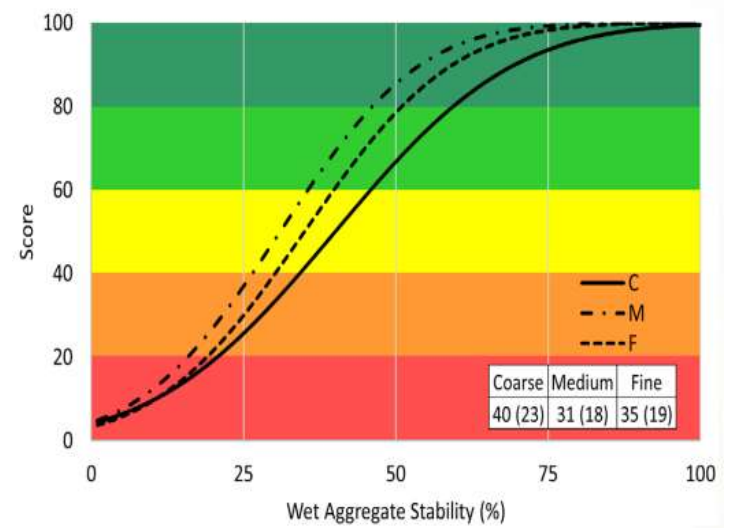


Om de bruikbaarheid van het indicatorsysteem te optimaliseren adviseren we om een continue classificatiesysteem te ontwikkelen op basis van bekende referentiewaarden voor alle bodemtype / landgebruik combinaties. Om de robuustheid en betrouwbaarheid van het indicatorsysteem te kunnen garanderen adviseren we om een dergelijk classificatiesysteem niet door de markt maar door de wetenschap (WUR) voor Nederland te laten ontwikkelen.

\section{Integrale beoordeling}

Een logisch vervolg op de samenstelling van een meetset die de afzonderlijke indicatoren bevat om bodemkwaliteit te beoordelen is een integrale beoordeling van de geselecteerde indicatoren. In onderzoek en praktijk zijn hiervoor reeds diverse systemen ontwikkeld en/of in gebruik (RBB, Bodempaspoort, BodemQ, BodemID). De gehanteerde werkwijzen verschillen van elkaar in de wijze warop gebruik wordt gemaakt van normalisatie en/of weging van de afzonderlijke indicatoren:

\section{Integrale beoordeling}

Een belangrijk aspect van de meting van de gehele indicatorset is de presentatie van de resultaten op een dergelijke wijze dat een goed beeld van de bodemkwaliteit kan worden gekregen. De aggregatie van de individuele indicatoren tot één enkel 'rapportcijfer' is discutabel omdat het aggregatieniveau van een dergelijk enkel cijfer zo hoog is dat jaarlijkse verschillen in bodemkwaliteit kunnen worden weggemiddeld waardoor het lijkt alsof er geen verandering is opgetreden.

De presentatie van de meetgegevens in de vorm van een zogenaamd 'spider-diagram' geeft op eenvoudige wijze veel informatie en ook verschillen tussen opeenvolgende metingen kunnen makkelijk worden gezien. Naar de uiteindelijke presentatie van resultaten moet goed worden gekeken en zo nodig worden afgestemd op verwachtingen en perceptieniveau.

\section{Normalisatie}

Normalisatie is het proces waarbij de eenheden van de afzonderlijke indicatoren worden omgezet naar een overkoepelende eenheid. Dit maakt het mogelijk om veranderingen in afzonderlijke indicatoren rekenkundig te bewerken en zo de totale verandering in bodemkwaliteit aan te geven. Een bekend voorbeeld vanuit de klimaatproblematiek is het uitdrukken van broeikasgasemissies in de $\mathrm{CO}_{2}$-equivalenten. Een mogelijkheid is om de meetwaarden komende uit de afzonderlijke indicatormetingen om te zetten naar een 'rapportcijfer' tussen 1 en 100, waarbij 1 zeer slecht is en 100 optimaal. Het dimensie-loos maken van de meetwaarden verhoogt het begrip en maakt kleine verschillen in de tijd zichtbaar. Een dergelijke omzetting kan worden gedaan door gebruik te maken van zogenaamde 'scorefuncties' die voor elke indicator en bodemtype / landgebruik combinatie uniek is.

Voor het algehele begrip en de vereenvoudiging van interpretatie van indicatormetingen wordt aanbevolen om scorefuncties op te stellen voor de afzonderlijke indicatoren.

\section{Weging}

Weging is het proces waarbij het relatieve belang van een indicator voor de algehele bodemkwaliteit kan worden aangegeven. Dit maakt bijvoorbeeld inzichtelijk hoe een minieme verandering in de belangrijkste indicator tot een wezenlijk andere beoordeling van de bodemkwaliteit kan leiden. In het voorbeeld van de broeikasgassen: een kleine verandering in lachgasemissie uit de bodem kan voor het klimaat van groter belang zijn dan een kleine verandering in koolstofvastlegging.

Om te komen tot een goede integrale beoordelingsmethode van de indicatorset voor bodemkwaliteit is het raadzaam om eerst ervaring op te doen met de afzonderlijke indicatoren en hun meetmethoden, referentiewaarden en nauwkeurigheden.

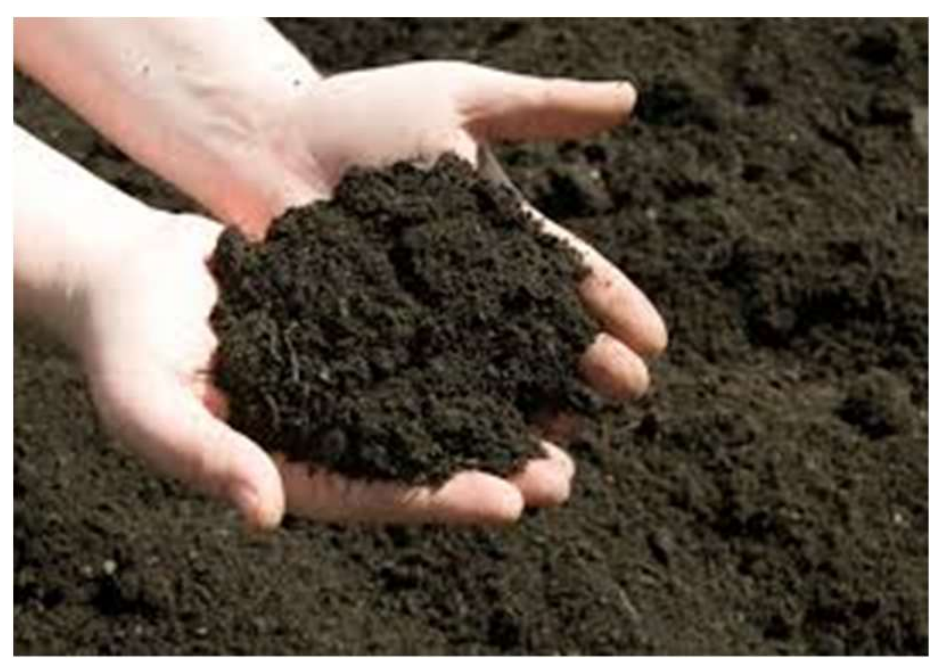

De missie van Wageningen University \& Research is 'To explore the potential of nature to improve the quality of life'. Binnen Wageningen University \& Research bundelen Wageningen University en

gespecialiseerde onderzoeksinstituten van Stichting Wageningen Research hun krachten om bij te dragen aan de oplossing van belangrijke vragen in het domein van gezonde voeding en leefomgeving. Met ongeveer 30 vestigingen, 5.000 medewerkers en 10.000 studenten behoort Wageningen University \& Research wereldwijd tot de aansprekende kennisinstellingen binnen haar domein. De integrale benadering van de vraagstukken en de samenwerking tussen verschillende disciplines vormen het hart van de unieke Wageningen aanpak.

(C) 2019 Wageningen, Stichting Wageningen Research, Postbus 9101, 6700 HB Wageningen; T 0317480700 ; www.wur.nl

Stichting Wageningen Research. Alle rechten voorbehouden. Niets uit deze uitgave mag worden verveelvoudigd, opgeslagen in een geautomatiseerd gegevensbestand, of openbaar gemaakt, in enige vorm of op enige wijze, hetzij elektronisch, mechanisch, door fotokopieën, opnamen of enige andere manier zonder voorafgaande schriftelijke toestemming van Stichting Wageningen Research.

Stichting Wageningen Research is niet aansprakelijk voor eventuele schadelijke gevolgen die kunnen ontstaan bij gebruik van gegevens uit deze uitgave. 